\title{
Evolutionary diversifications of plants on the Qinghai-Tibetan Plateau
}

\author{
Jun Wen ${ }^{1}$, Jian-Qiang Zhang ${ }^{2}$, Ze-Long Nie $^{3}$, Yang Zhong ${ }^{4,5}$ and Hang Sun ${ }^{3}$ * \\ ${ }^{1}$ Department of Botany, National Museum of Natural History, MRC 166, Smithsonian Institution, Washington, DC, USA \\ ${ }^{2}$ College of Life Sciences, Peking University, Beijing, China \\ ${ }^{3}$ Key Laboratory for Plant Diversity and Biogeography of East Asia, Kunming Institute of Botany, Chinese Academy of Sciences, Kunming, China \\ ${ }^{4}$ Institute of Biodiversity Science and Geobiology, Tibet University, Lhasa, China \\ ${ }^{5}$ School of Life Sciences, Fudan University, Shanghai, China
}

\section{Edited by:}

Federico Luebert, Universität Bonn, Germany

\section{Reviewed by:}

Jianquan Liu, Lanzhou University; Sichuan University, China

Stefanie M. Ickert-Bond, University of Alaska Fairbanks, USA

\section{*Correspondence:}

Jun Wen, Department of Botany, National Museum of Natural History, MRC 166, Smithsonian Institution, Washington, DC 20013-7012, USA e-mail:wenj@si.edu; Hang Sun, Key Laboratory for Plant Diversity and Biogeography of East Asia, Kunming Institute of Botany, Chinese Academy of Sciences, Kunming 650204, China e-mail:hsun@mail.kib.ac.cn
The Qinghai-Tibetan Plateau (QTP) is the highest and one of the most extensive plateaus in the world. Phylogenetic, phylogeographic, and ecological studies support plant diversifications on the QTP through multiple mechanisms such as allopatric speciation via geographic isolation, climatic oscillations and divergences, pollinator-mediated isolation, diploid hybridization and introgression, and allopolyploidy. These mechanisms have driven spectacular radiations and/or species diversifications in various groups of plants such as Pedicularis L., Saussurea DC., Rhododendron L., Primula L., Meconopsis Vig., Rhodiola L., and many lineages of gymnosperms. Nevertheless, much work is needed toward understanding the evolutionary mechanisms of plant diversifications on the QTP. Wellsampled biogeographic analyses of the QTP plants in the broad framework of the Northern Hemisphere as well as the Southern Hemisphere are still relatively few and should be encouraged in the next decade. This paper reviews recent evidence from phylogenetic and biogeographic studies in plants, in the context of rapid radiations, mechanisms of species diversifications on the QTP, and the biogeographic significance of the QTP in the broader context of both the Northern and Southern Hemisphere biogeography. Integrative multidimensional analyses of phylogeny, morphological innovations, geography, ecology, development, species interactions and diversifications, and geology are needed and should shed insights into the patterns of evolutionary assembly and radiations in this fascinating region.

Keywords: evolutionary radiations, Qinghai-Tibetan Plateau, QTP, biogeography, allopatric speciation, vicariance

\section{INTRODUCTION}

The Qinghai-Tibetan Plateau (QTP) is the highest and one of the most extensive plateaus in the world, covering an area of $2.5 \times 10^{6} \mathrm{~km}^{2}$ with an average elevation of more than $4000 \mathrm{~m}$ (Zhang et al., 2002; Geng et al., 2009). The QTP is generally delimited by the Qilian and the Kunlun Mountains in the north, the Himalayan Mountains in the south, the Karakorum Range of Pakistan in the west, and the Hengduan Mountains in the east (Figure 1A; Wu et al., 1995; Turner et al., 1996; Zhang et al., 2002). The uplifts of the plateau were driven by the collision of the Indian plate with the Eurasian plate, which began at ca. 50 million years ago (mya; Coleman and Hodges, 1995; Rowley and Currie, 2006; Royden et al., 2008). Since the early Miocene, extensive uplifts of the QTP occurred in at least four major periods: 25-17, 15-13, 8-7, and 3.5-1.6 mya (see Harrison et al., 1992; Li et al., 1995; Shi et al., 1998; Guo et al., 2002; Spicer et al., 2003). The plateau harbors more than 12,000 species of vascular plants in 1500 genera, with the Hengduan-Himalayan region of the eastern and southern parts of the QTP possessing exceptional species richness and a high level of endemism (Wu, 1988; Li and Li, 1993), especially for alpine elements (Wu et al., 1995; Liu et al., 2000). Nevertheless a few recent studies examined the evolution of unique endemic plants and have found that several monotypic plant genera in the alpine regions of the QTP are nested within larger genera (see Friesen et al., 2000; Tian et al., 2011; Nie et al., 2013).

The various QTP uplift events between the early Miocene and the Quaternary, in association with the zonal climate pattern of the Paleogene controlled by desert and steppe climates (Zhang et al., 2012b) transforming into a monsoon-dominated pattern similar to the present-day one in the Neogene (Guo et al., 2008), have been shown to have triggered and facilitated plant speciation and diversifications (see Wang et al., 2007b; Qiu et al., 2011). Some of the plant lineages diverged following the early uplifts of the QTP, or even prior to the formation of the plateau (Liu et al., 2002a; Yang et al., 2003; Zhang and Fritsch, 2010; Sun et al., 2012). Most studies support divergences in the last $5 \mathrm{Ma}$, such as in Rheum $\mathrm{L}$. (Wang et al., 2005), Sinacalia H. Rob. \& Brettell (Liu et al., 2006), and Solms-laubachia (Maxim.) Botsch (Yue et al., 2009).

Many phylogeographic studies have been conducted in the past decade to explore the evolutionary consequences of climatic fluctuations and complex local topography and geomorphology of the QTP and its surrounding regions (see reviews by Geng et al., 2009; Qiu et al., 2011; Liu et al., 2012; also see Yang et al., 2009 for perspectives on animal lineages). Multiple refugia have been inferred 


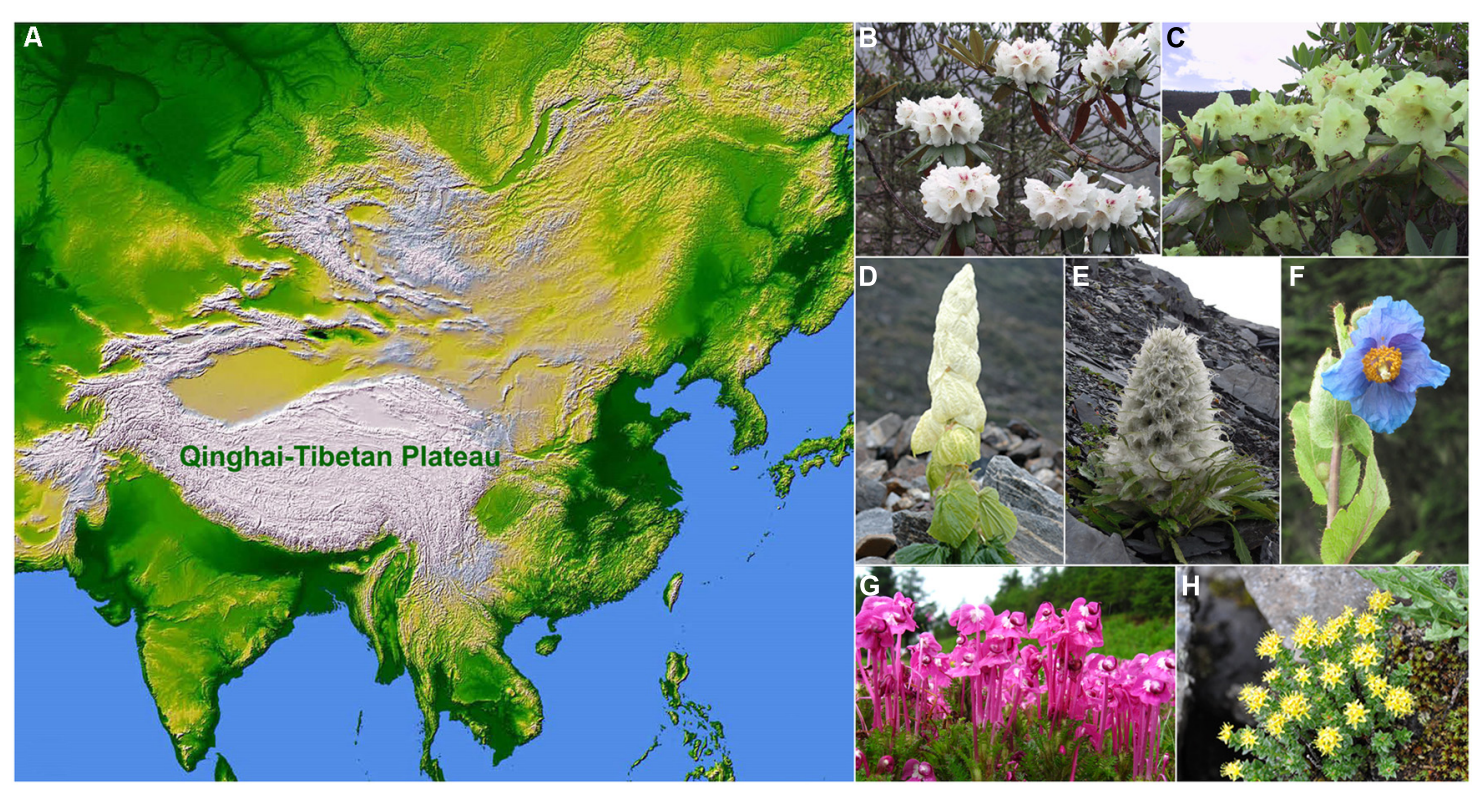

FIGURE 1 | Geographic location of the Qinghai-Tibetan Plateau (A) and representative plant groups: (B) Rhododendron roxieanum Forrest ex W.W.Sm.; (C) Rhododendron wardii W.W.Sm.; (D) Rheum nobile Hook.f. \& Thoms., showing "glasshouse-like" morphology; (E) Saussurea laniceps Hand.-Mazz., showing "snow-ball" morphology; (F) Meconopsis betonicifolia Franch.; (G) Pedicularis siphonantha D.Don var. delavayi (Franch. ex Maxim.) P.C.Tsoong; and (H) Rhodiola alsia (Fröd.) Fu (photo credit: B,C,G by $\mathbf{H}$. Sun; D,F by J. Wen; $\mathbf{E}$ by B. Song; and $\mathbf{H}$ by J. $\mathbf{Q}$. Zhang). in the peripheral regions of the QTP based on results from many plant lineages (Liu et al., 2012). The southeastern QTP has been suggested to harbor glacial refugia in several lineages of plants and animals especially during the Last Glacial Maximum (LGM; Chen et al., 2008; Yang et al., 2008a; Zhang et al., 2010; Zhou et al., 2013a). Several studies suggested refugia in the Hengduan Mountains on the eastern border of the QTP (Zhang et al., 2010; Wang et al., 2011b). It has been suggested that advances of the Tibetan glaciers were less prominent than other regions in the Northern Hemisphere, likely due to arid conditions and complex topography, and potential habitats for cold-tolerant species could be found in the plateau and served as refugia in the interior Central regions of the QTP during interglacial periods in the Quaternary (Schäfer et al., 2002; Wang et al., 2009a, 2011b; Shimono et al., 2010).

A number of studies have explored macro-evolutionary relationships (Wang et al., 2005, 2009c; Liu et al., 2006; Zhang et al., 2011a; Eaton and Ree, 2013; Zhou et al., 2013b) and the impact of aridization of interior Asia on plant population structure and speciation (Zhang and Fritsch, 2010; Zhang et al., 2012a). This paper reviews recent evidence from phylogenetic and biogeographic studies in plants, in the context of rapid radiations, mechanisms of species diversifications on the QTP, and the biogeographic significance of the QTP in the broader context of Northern Hemisphere biogeography.

\section{SPECTACULAR RADIATIONS}

Several spectacular rapid radiations (Figures 1B-H) have been reported to be triggered by extensive uplifts of the QTP, which caused drastic habitat fragmentation (Liu et al., 2006; Wang et al., 2007b) and resulted in the rapid expansion of cold and dry habitats by strengthening the Asian monsoon climate (An et al., 2001). The mechanisms of the QTP plant radiations and diversification certainly go beyond allopatric speciation. Other mechanisms especially pollinator-mediated isolation, hybridization and introgression, allopolyploidy, and morphological innovations have also been proposed. In a strict sense, evolutionary radiations represent many species or lineages evolved from a common ancestor in a short time period (Wen etal., 2013). Due to the fact that evolutionary radiations and species diversifications have not been well analyzed for the QTP plants, we included discussions of plant groups, which are highly species-rich on the QTP.

An extraordinary species-rich group on the QTP, especially the Hengduan Mountains is the genus Pedicularis L. (Orobanchaceae). The genus consists of about 600 species with over 270 species endemic to the mountains of SW China and is also widespread in alpine and cold areas of the Northern Hemisphere (Yang et al., 1998; Ree, 2005). Species of Pedicularis exhibit unusual diversity of floral characters (Yang et al., 2003) and they are mainly obligate outcrossers and are pollinated by bumblebees (Macior and Sood, 1991; Macior and Tang, 1997; Macior et al., 2001; Wang and Li, 2005; Eaton et al., 2012; Huang and Shi, 2013). Eaton et al. (2012) reported that local species richness of Pedicularis in SW China is best explained by a model including both floral diversity and phylogenetic distance. A mosaic of pollinator-mediated interactions among Pedicularis species promotes ecological sorting through recurrent selection against reproductive interference, which explains the rapid species turnover at local scales, and drives floral divergence among species. 
Species of Rhododendron L. are common members of the SinoHimalayan region in the southern part of the QTP. The genus consists of about 1025 species with many narrow endemics often sympatric with interfertile congeners throughout their ranges (Fang and Min, 1995; Milne, 2004; Goetsch et al., 2005). Rhododendron subgenus Hymenanthes appears to have undergone rapid radiations in the Sino-Himalayan region, with about 200 species in the region and the adjacent areas in China (Chamberlain, 1982; Fang and Min, 1995). Hybridizations, habitat fragmentation, and isolation through elevational changes have been hypothesized to be important for the radiation of species of subgenus Hymenanthes (Blume) K.Koch (Fang and Min, 1995; Zha etal., 2008; Milne etal., 2010). All Rhododendron subgenus Hymenanthes species are diploids $(2 n=26)$, and hybridizations are commonly recorded among taxa, even between distantly related species (Chamberlain, 1982; Zha et al., 2008, 2010). Yet speciation via hybridization needs to be rigorously tested in Rhododendron on the QTP.

Meconopsis Vig. of Papaveraceae, the well-known blue-poppy genus of the Himalaya, consists of about 50 species on the QTP and adjacent regions in the Himalaya (Yang et al., 2012). One species, Meconopsis cambrica Vig. is native to Europe, and has been shown that it does not belong in the genus (Kadereit et al., 1997, 2011). Meconopsis is resolved as sister to sect. Meconella Spach of Papaver L. (Carolan et al., 2006; cf. Jork and Kadereit, 1995; Kadereit et al., 1997). Yang et al. (2012) suggest that geographic isolation and hybridization are two important mechanisms for speciation in Meconopsis, a genus also with polyploids, implying the role of allopolyploidy in the species radiation of the blue-poppy genus on the QTP.

Rhodiola L. (Crassulaceae) is a genus consisting of about 90 species, most of which distributed in QTP and adjacent areas (Fu and Ohba, 2001). Molecular phylogenetic studies (Zhang et al., 2014) revealed significant convergence of previously thought important morphological characters, i.e., dioecy and marcescent flowering stems, which made most of previous infrageneric taxa non-monophyletic (e.g., Ohba, 1978; Fu and Fu, 1984). The biogeographic analyses suggest a rapid radiation triggered by the uplift of the QTP during the middle Miocene (Zhang et al., 2014). Radiation continued in the later evolutionary process and some lineages dispersed into other regions (e.g., Central Asia, and North America) of the Northern Hemisphere. Allopolyploidy may also have played a role in the radiation of Rhodiola on the QTP, as the genus has been recorded with allopolyploids (Zhang et al., 2014).

Rapid radiations have been reported in several lineages of Asteraceae on the QTP, such as Ligularia Cass.-Cremanthodium Benth.Parasenecio W.W.Sm. \& J.Small (L-C-P) complex (Liu et al., 2006), the Dolomiaea DC.-Diplazoptilon Y.Ling-Xanthopappus C.Winkl. group (Wang et al., 2007b), Saussurea (Wang et al., 2009c), Leontopodium R.Br. ex Cass. (Blöch et al., 2010; Safer et al., 2011), and the Soroseris Stebbins-Stebbinsia Lipsch. group (Zhang et al., 2011a). In all these studies, levels of substitution and support for internal branches in the phylogenetic analyses are low, and morphologically diverse species often group together. The rapid diversification pattern has been explained by habitat fragmentation and heterogeneity followed by climatic changes during the uplift of the Himalayas and the Tibetan Plateau in the late Tertiary (Liu et al., 2006; Royden et al., 2008). We discuss the LC-P complex of the Tussilagininae (Senecioneae) and Sausurrea as case studies to illustrate this common pattern of radiation on the QTP.

The L-C-P complex contains more than 200 species endemic to the QTP. The eleven genera in an expanded L-C-P complex constitute a largely unresolved L-C-P complex clade, which was suggested to have originated as a rapid radiation mostly within the last $20 \mathrm{Ma}$. The age estimates correlate with the period of recent major uplifts of the QTP between the early Miocene to the Pleistocene. Liu et al. (2006) suggested vicariance and ecological diversity associated with the QTP uplifts most likely promoted rapid and continuous allopatric speciation in small and isolated populations, and facilitated morphological convergence in the L-C-P complex. Other mechanisms including diploid hybridization in secondary sympatric conditions were proposed for the L-C-P complex as well.

Saussurea (Cardueae) of Asteraceae is a genus of over 450 species, with a high level of endemism on the QTP (ca. 230 species), ca. 150 species in Central Asia to the Russian Far East, and ca. 100 species in eastern Asia (Lipschitz, 1979; Kita et al., 2004; Wang et al., 2009c). The phylogenetic analyses (Wang et al., 2009c) suggest that Saussurea s.l. is a polyphyletic group with several parallel clades of the lineage, supporting island-like adaptive radiations in a continental setting and morphological convergences on the QTP. The dating results suggest that this radiation occurred 14-7 mya, during the period of the major uplift events of the QTP.

However, Nie et al. (2013) reported that the diversification in Anaphalis DC. of Asteraceae on the QTP is much more complex and cannot be explained using a single radiation event. The extant Anaphalis in the eastern Himalaya consists of at least four independent lineages. The diversifications of these four groups followed different patterns. Clade I contains only one species commonly found from the western to the eastern Himalaya, extending as far as southeastern Asia to the Philippines. There is apparently no radiation in clade I but its wide distribution has perhaps resulted from dispersals. The widest distribution of clade II among the four Anaphalis groups, ranging from central Asia through the Himalaya to northeastern and southeastern Asia, is probably due to dispersal. The intercontinental disjunction between North America and Asia within this clade was hypothesized to have resulted from a recent dispersal event from Asia to North America. However, the poorly resolved relationships of taxa within clade II may be due to a rapid radiation. Seeds in Anaphalis can be small and light, and possess a pappus, which may be well adapted for wind dispersal. Clade III is composed of about four species and they are mainly restricted to the Himalayan region (Ling, 1979). However, little sequence variation was observed within this clade in spite of the highly distinctive morphology between A. busua DC. and the A. contorta Hook.f. group. Clade IV is a highly diversified group in the eastern Himalayas and the Hengduan Mountains of SW China, but species relationships within this clade in general are weakly supported due to low rates of sequence divergence, perhaps supporting an evolutionary radiation. 


\section{MECHANISMS OF SPECIES DIVERSIFICATION ON THE OTP}

Below we discuss these mechanisms with a few case studies. For a given plant group, more than one such mechanism may have played a role, even though we discuss them separately.

\section{ALLOPATRIC DIVERGENCE}

Vicariant allopatric speciation associated with the geologic uplifts has been proposed as the main mechanism of species diversification of plants and animals on the QTP (Yang et al., 2009; Xu et al., 2010). The plateau has many high mountains and plains incised deeply by numerous valleys or rivers, forming an extremely complex topography with diverse habitats.

Phyllolobium is a genus as a recent segregate from Astragalus, and contains about 20 species and four sections mostly endemic to the QTP. Zhang et al. (2012a) hypothesized Phyllolobium as a recently diversified genus adapted to the cold and dry habitats of the QTP. The crown of Phyllolobium was dated to the Pliocene: 3.62-3.96 Ma, and sections within the genus had ages ranging between 3.60 and $2.55 \mathrm{Ma}$. These dates coincide with the intense uplift of the QTP in the late Pliocene. The diversification of sections Bibracteolati and Oliganthum began at estimated ages of 1.95 and $1.83 \mathrm{Ma}$, respectively. The estimated crown ages of Phyllolobium and its sections suggest that rapid diversification was likely triggered by consecutive phases of the QTP uplifts in the late Pliocene and the early-to-mid Pleistocene. The diversification of some Phyllolobium species can be explained by late Pleistocene glaciations and/or geologic events.

$\mathrm{Xu}$ et al. (2010) report a case study on eight Cupressus species, with each having a mainly allopatric distribution on the QTP and adjacent regions. The phylogenetic and network analyses showed that most DNA haplotypes recovered or haplotype lineages resolved were species-specific, and are consistent with allopatric divergences.

Qin et al. (2013) investigated the evolutionary history of 14 Ephedra species from the QTP and northern China. The phylogeographic and phylogenetic analyses support three main lineages (eastern QTP, southern QTP, and northern China) of these Ephedra species. Divergence of each lineage was dated to the middle-to-late Miocene, a period with the active uplifts of the QTP and the Asian aridification.

Soroseris, Stebbinsia, and Syncalathium of Asteraceae are three genera endemic to the high screes of the QTP (Zhang et al., 2011a). The diversification of these groups in the Tibetan Plateau is of relatively young age, with the stem and crown ages of the SoroserisStebbinsia clade and the two groups of Syncalathium estimated between 8.44 and 1.56 Ma. The evolution of the groups on the QTP is hypothesized to be characterized by rapid diversification and radiation of the Soroseris-Stebbinsia clade, allopatric speciation within Syncalathium s. str. and convergent evolution of Syncalathium s.str. and Syn. souliei. The speciation events are correlated with climatic changes and fragmentation of scree habitats during the uplifts of the QTP.

Cyananthus Wall. ex Benth. (Campanulaceae) contains ca. 20 species with a typical Sino-Himalayan distribution (Hong et al., 2011). Most Cyananthus species are prominent components of alpine meadows at high altitudes in the Sino-Himalayan region, and many species are narrow endemics with a few widespread taxa (Hong and Ma, 1991; Shrestha, 1997). Zhou et al. (2013b) reconstructed the processes of biogeographic diversification in the region using Cyananthus as a model. Molecular dating and biogeographic analysis support dispersal from the Himalayas to the Hengduan Mountains during the early evolution of Cyananthus. The early diversification event that resulted in the split of the two main lineages within Cyananthus was estimated to have taken place between 5.98 and 12.46 mya, coinciding with the third extensive period of the QTP uplift since the Miocene. Zhou et al. (2013b) suggests that dispersal was the main mechanism of early diversification of Cyananthus, and that the vicariance triggered by the uplift of the QTP accelerated the divergence between sect. Cyananthus and the two other sections of the genus, with sect. Cyananthus mainly in Himalayas and the two other sections originated in the Hengduan regions.

At the shallower intraspecific level, vicariance by topography has been reported in a large number of recent phylogeographic analyses, such as in Aconitum gymnandrum Maxim. (Wang et al., 2009a), Hippophae tibetica Schltdl. (Jia et al., 2011), and Incarvillea sinensis Lam. (Chen et al., 2012), suggesting the ongoing contribution of vicariance on the QTP to plant evolution and differentiation.

\section{CLIMATIC OSCILLATIONS AND DIVERGENCES}

The Tertiary and Quaternary climatic oscillations associated with the QTP uplifts have been widely discussed in facilitating speciation and diversification (Sun, 2002a,b), and shaping geographic genetic structure and the recolonization patterns from multiple refugia on the QTP (Cun and Wang, 2010; Qiu et al., 2011; Liu et al., 2012) and in a broader geographic context (see Hewitt, 2000, 2004). The rapid uplifts of the QTP have also led to drastic climatic divergences on the plateau, which have been largely controlled by the Indian summer monsoon (Wang and LinHo, 2002). The Indian summer monsoon has brought heavy summer rainfall to the southern part of the Himalayas, with decreasing precipitation in other areas of the QTP since the late Miocene (An et al., 2001). The impact of the climatic oscillations and divergences has been confirmed in various groups of plants (Yang et al., 2012; Zhou et al., 2013b), with many recent studies emphasizing the glacial and interglacial climatic oscillations in the Quaternary (see review by Qiu et al., 2011). The recent phylogeographic study of Sophora davidii Kom. ex Pavol. also provides support for a climatically driven barrier to present-day plant dispersal across the “Tanaka-Kaiyong Line” (Fan et al., 2013a).

\section{HYBRIDIZATION AND INTROGRESSION}

Interspecific diploid hybridization has been suggested to have contributed to the high species diversity on the QTP and adjacent areas, because of secondary sympatry during relatively stable stages between different uplifts of the QTP (Wang et al., 2001; Liu et al., 2006). Hybridization has been proposed to have played an important role in the spectacular radiations of several plant groups such as Rhododendron at the southern part of the QTP in the Sino-Himalayan region (Zha et al., 2010; also see Milne et al., 2010), and Meconopsis on the QTP (Yang et al., 2012). The homoploid hybrid speciation of Pinus densata Masters, a high mountain pine endemic to the QTP has been rigorously documented in 
a series of studies with the parental species as $P$. tabulaeformis Carrière and P. yunnanensis Franch. (Wang et al., 2001, 2011a; Song et al., 2002, 2003; Ma et al., 2006). Nevertheless, although both hybridization and introgression have been confirmed among species in nature on the QTP (e.g., Li et al., 2008; Zhu et al., 2009), the general impact of hybridization and introgression on plant speciation on the QTP has remained poorly studied so far.

\section{MORPHOLOGICAL CONVERGENCE AND INNOVATIONS}

A number of previous studies have shown that rapid species diversification occurred in response to the extensive uplift of the QTP and resulted in numerous morphologically distinct species, in which morphological traits appear to be ecologically adaptive, thus extensive morphological convergences have been documented (Liu et al., 2006; Wang et al., 2009a; Xie et al., 2011; Zhang et al., 2014). Species on the QTP from different lineages might have been under similar selection pressure after the uplifts of the plateau. This may explain the extensive morphological convergent evolution observed. For example, Parasyncalathium souliei (Franch.) J.W.Zhang, Boufford \& H.Sun was once treated as a species of Syncalathium Lipsch. due to very similar morphological outline to other species of Syncalathium (Crepidinae); and it has been recently transferred into Lactucinae as a new genus based on recent molecular, cytological and morphological evidence (Zhang et al., 2011b). Other well-known examples of morphological convergences of the QTP plants include "cushion" plants (Li et al., 1985; Wang et al., 2004), "glasshouse" morphology (Ohba, 1988), and "snow-ball" plants with densely villous aggregated globose or spiciform synflorescences (Ohba, 1988; Tsukaya and Tsuge, 2001; Tsukaya et al., 2002; Kita et al., 2004; Yang et al., 2008b).

The "glasshouse-like" morphology of plants on the QTP is a well-known morphological innovation and is worthy of more discussions. The upper leaves of plants have developed into large translucent cream-colored bracts that cover the inflorescences (Tsukaya and Tsuge, 2001; Yoshida, 2002). These bracts may play a critical role in protecting pollen grains from damage by low temperatures and ultraviolet (UV) radiation (Omori et al., 2000), maintaining warmth inside the inflorescence (Terashima et al., 1993), and enhancing seed productions (Yang and Sun, 2009; Song et al., 2013). The "glasshouse" morphology has been documented in more than 10 plant families, which indicates obvious convergence of this character in diverse groups (Ohba, 1988). Phylogenetic studies including both "glasshouse" plants and "non-glasshouse" plants in Saussurea and Rheum L. revealed convergent evolution of this body-plan trait even within a single genus (Wang et al., 2009c; Sun et al., 2012). A recent study compared the homologous candidate genes with the same expression changes between the two "glasshouse" species in Rheum, $R$. nobile Hook.f. \& Thoms. and R. alexandrae Batalin, and concluded that the "glasshouse" phenotypes may have common molecular bases underlying their convergent evolution of similar adaptive functions (Zhang et al., 2010; Liu et al., 2013). However, it is still unknown whether the convergent evolution of this phenotype has the same molecular mechanism on a larger scale and in other groups.

\section{BIOTIC INTERACTIONS: POLLINATOR-MEDIATED ISOLATION}

Many species-rich plant lineages such as Corydalis Vent., Gentiana L., Meconopsis, Pedicularis, Saussurea, Aconitum L., and Delphinium L. are pollinated by bumblebees (He et al., 2006; Duan et al., 2007, 2009; Hou et al., 2008; Niu et al., 2011; Eaton et al., 2012) with congeners commonly co-occurring at local scales on the QTP. Closely related species of the plant genus Pedicularis co-occur geographically, share pollinators (bumblebees), and exhibit high floral diversity and species richness on the QTP. Biotic, especially pollinator-mediated, interactions among the Pedicularis species have been hypothesized to promote ecological sorting through recurrent selection against reproductive interference, which explains the rapid species turnover at local scales, and drives floral divergence among species of Pedicularis (Eaton et al., 2012). Whether pollinator-mediated reproductive interference is unique in Pedicularis or has played a more general role in the regional plant diversifications need to be further explored with comparative studies of pollination ecology, reproductive biology, and phylogenetic community structure. Duan et al. (2009) reported that a combination of insect and wind pollination may have played an important role in maintaining sexual reproduction of the biennial herbaceous species Aconitum gymnandrum, and may have allowed the species to persist in arid habitats on the QTP during Quaternary glacial periods when there were extensive oscillations of pollinator populations. Also Hou et al. (2008) compared sympatric gentian species sharing the same pollinator, yet they differ in phenology, with incomplete pollination isolation. The role of such isolation mechanisms needs to be explored in large groups, such as Pedicularis, Rhododendron, and Primula L.

\section{POLYPLOIDY}

Polyploidy is considered to be one of the most important cytogenetic mechanisms in plant evolution (Stebbins, 1940, 1971; Mayrose et al., 2011). Polyploidy is relatively common in plants of cold climates with harsh environments, especially in alpine and arctic regions (Löve and Löve, 1967; Grant, 1981; Stebbins, 1984; Brochmann et al., 2004). A common explanation of this pattern is that polyploids possess broader ecological tolerances than their diploid parents/relatives and may be more efficient to adapt to new habitats (Stebbins, 1984; Soltis and Soltis, 1999, 2000; Brochmann et al., 2004; Otto, 2007). The QTP has the highest mountains and the most extreme environment in the world, and the advancement and retreat of ice sheets and glaciers since the Quaternary have created new habitats for vegetative colonization of polyploids.

No statistic chromosomal data are available from the QTP, however, Nie et al. (2005a) have indicated that polyploidy may have played only a minor role in the evolutionary diversification in the Hengduan Mountains, which is located on the eastern border of the QTP. Wu et al. (1995) also reported their observations on the low frequencies of polyploids in the alpine flora of the QTP. Based on the statistical analysis of the chromosome data of 552 taxa of native angiosperms, Nie et al. (2005a) reported that the frequency of infrageneric polyploidy is only $22 \%$. Several highly diversified groups, such as Cremanthodium (Liu et al., 2001), Ligularia (Liu et al., 2006), and Delphinium (Yuan and Yang, 2008), also show a low proportion of polyploidy on the QTP and adjacent 
areas. Examples from other endemic genera (e.g., Syncalathium, Soroseris, Solms-laubachia Muschl., Tibetia (Ali) H.P.Tsui, and Nomocharis Franch.) again indicated that polyploidy, especially infrageneric polyploidy, may have played a minor role on the evolutionary diversification of these plants in this region (Xie et al., 1992; Nie et al., 2002; Yue et al., 2004; Zhang et al., 2007, 2009a).

However, cytological investigations on several other groups have suggested the importance of polyploidy. Leontopodium is the second largest genus within the Asian Gnaphalieae (Asteraceae) and is most speciose on the QTP and its adjacent areas in SW China. The chromosome numbers and karyomorphology of five species from this region suggests that the basic chromosome number of Leontopodium is $x=14$, followed with dysploidy numbers (e.g., $x=12,13$ ), and that three of the five species examined are polyploids (Meng et al., 2012). Dysploidy and polyploidy observed in Leontopodium may have facilitated the adaptation of Leontopodium to diverse habitats on the QTP. Luo et al. (2011) examined the chromosomes of Silene L. from high elevations of the Hengduan Mountains, and reported the basic chromosome number as $x=12$. So far only seven species of Silene, which has its diversity center in the Hengduan Mountains, have been reported with cytological data, of which three species are polyploids. Chen et al. (2007) reported 10 of the 18 Buddleja L. species in the Hengduan Mountains to be polyploids. Several other cases also found that polyploidy is common in plants in the alpine areas of the eastern Himalaya and the Hengduan Mountains, such as in Aconitum subgenus Lycoctonum (DC.) Peterm. (Yuan and Yang, 2006), Rheum (Liu et al., 2010), and Anaphalis (Meng et al., 2010). Wu et al. (2010) suggested that the tetraploid cytotypes of Allium przewalskianum Regel had evolutionary advantages over diploids in colonizing and/or surviving the arid habitats of the QTP.

Clearly polyploidy has played a role in the evolutionary diversification of some plant groups on the QTP. Further investigations of characteristic groups of the QTP region, possibly with different evolutionary histories, are needed to more precisely evaluate the role of polyploidy in the speciation on the QTP, in comparison to other alpine regions.

\section{BIOGEOGRAPHIC CONNECTIONS OF THE OTP WITH OTHER REGIONS}

The Tethyan Tertiary flora and the Arcto-Tertiary flora have been suggested as important sources of the QTP alpine and forest floras (Sun, 2002a,b; Zhou et al., 2013b). Examples of Tethyan Tertiary elements include Helleborus L. (Sun et al., 2001), Incarvillea Juss. (Chen et al., 2005), Mandragora L. (Tu et al., 2010), Hyoscyamus L. (Tu etal., 2010), Pistacia L. (Yi et al., 2008; Xie et al., 2014), and Ruta L. (Salvo et al., 2010). The Arcto-Tertiary elements are exemplified by Rhododendron L. (Kron, 1997), Aralia L. (Wen et al., 1998; Wen, 2011), Panax L. (Wen and Zimmer, 1996; Lee and Wen, 2004); Circaea L. (Xie et al., 2009), Triosteum L. (Gould and Donoghue, 2000), Maianthemum Wiggers (Meng et al., 2008), and Astilbe Buch.-Ham. ex D.Don (Zhu et al., 2013). The Turgai Strait stretching from the Arctic Ocean to the Tethys Seaway separated the European and Asian floras through the Paleocene to the early Oligocene (Tiffney, 1985). The closure of the Turgai Strait brought about a drier and cooler continental climate across Central Asia, and allowed extensive biogeographic exchanges between
Asia and Europe (Tiffney and Manchester, 2001). So far a relatively few number of studies have been conducted to explore the biogeographic significance of the QTP in the Northern Hemisphere based on modern phylogenetic evidence. We thus attempt a review to summarize the available evidence (also see Figures $2 \mathrm{~A}-\mathrm{F}$ ) and hope that this will present the QTP as an exciting region for colleagues beyond eastern Asia.

THE OTP AS A BIOGEOGRAPHIC SOURCE AREA IN EURASIA (Figure 2A) Several lineages have been inferred to have originated on the QTP and subsequently migrated into the other regions of Eurasia, i.e., the out-of-QTP hypothesis (e.g., in Wang et al., 2004; Fan et al., 2013b; Zhang et al., 2013). One case is Gentiana sect. Cruciata Gaudin, which is mainly distributed in alpine areas in Eurasia, with the greatest species diversity on the QTP (Zhang et al., 2009b). The phylogenetic analyses support the monophyly of the section with five major clades identified. The basalmost clade comprised three species that were endemic to the QTP. The clade that diverged second was represented by three Central Asian species. The European clade, containing only G. cruciata L., grouped with the remaining two clades constituting species from the QTP and Central Asia. The biogeographic analyses and divergence time estimates suggested that this section diversified initially on the QTP within $4 \mathrm{Ma}$. The results support the biogeographic significance of the QTP for alpine plant evolution, and the lineage then migrated to Central Asia and Europe from the QTP and/or western China after the Pliocene when global temperatures decreased.

Lagotis J.Gaertn. is a small genus of herbaceous plants of Plantaginaceae containing about 28 species mainly occurring on the QTP, Central Asia, arctic and subarctic Asia, and Northwest America. The centers of diversity of this genus are on the QTP (15 endemic species) and in Central Asian Mountains (eight endemic species). Molecular biogeographic analyses suggested the origin of Lagotis on the QTP in the Miocene with its subsequent radiations from the Miocene to Pleistocene. The diversification of Lagotis probably took place predominantly in the QTP and it then spread to the Central Asian highlands, supporting the "Central Asiatic Highland Corridor" as proposed by Ohba (1988), followed by the northward migration into the arctic (Li et al., 2014).

A similar pattern has been documented in Rhodiola L. (Crassulaceae; Zhang et al., 2013), Androsace L. (Primulaceae; Wang et al., 2004), Leontopodium (Blöch et al., 2010; Safer et al., 2011), Anaphalis (Nie et al., 2013), and Koenigia L. (Fan et al., 2013b).

The out-of-QTP scenario was also shown at the shallower scale. For example, haplotype distribution pattern, as well as coalescence and molecular variance analyses of the fern Lepisorus clathratus Ching from mainly the QTP and north-central China suggest that populations in the Hengduan Mountains possess the highest genetic diversity, whereas a single haplogroup is found across the north-central region of China, supporting the hypothesis of recolonization from the glacial refugia of the QTP into the north-central regions of China northward into the Altai during interglacial periods (Wang et al., 2011b). Other cases of the outof-QTP colonization pattern within a species have been reported, such as in Hippophae rhamnoides L. (Jia et al., 2012) and Sophora davidii (Fan et al., 2013a). 


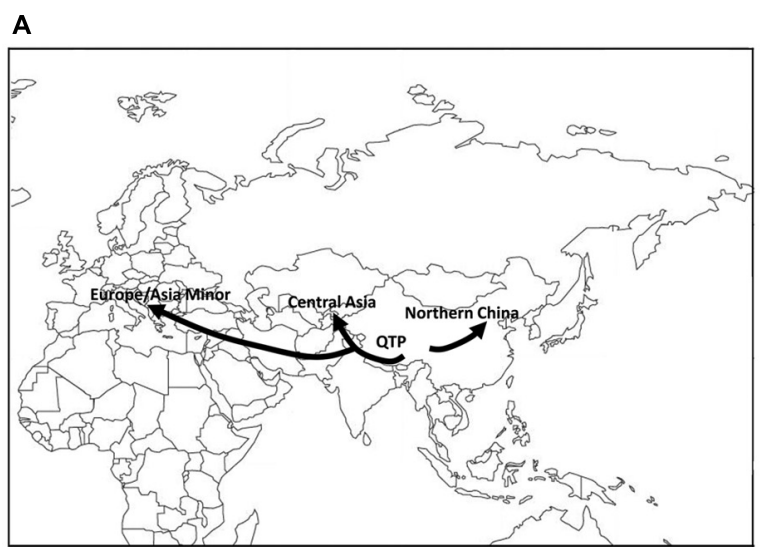

C

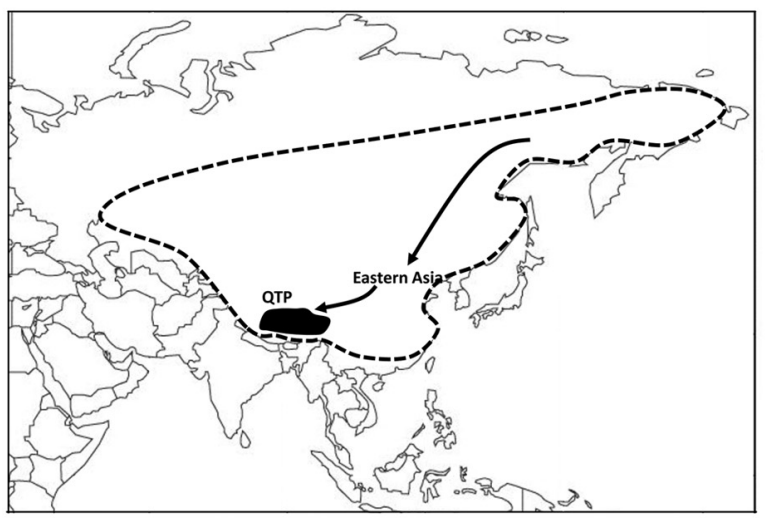

E

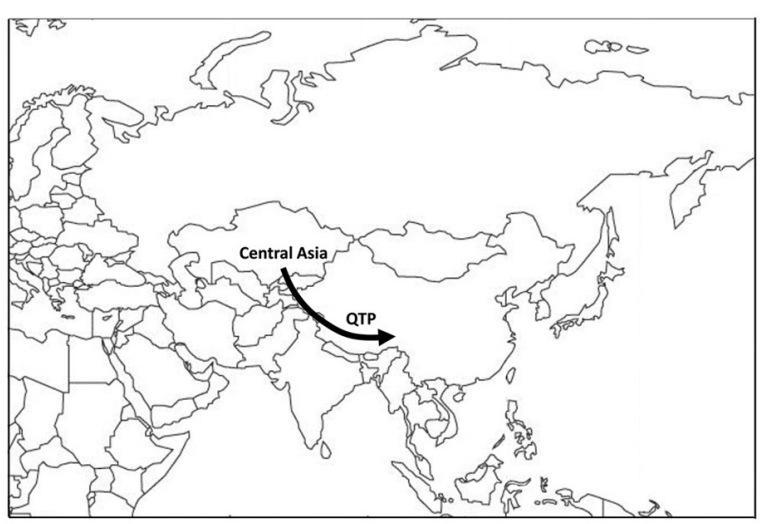

FIGURE 2 | Major patterns of biogeographic diversification of plants on the Qinghai-Tibetan Plateau: (A) the OTP as a biogeographic source area in Eurasia with examples of Gentiana sect. Cruciata Mang etal., 2004) and Hippophae rhamnoides (Jia etal., 2012); (B) close biogeographic connections of the QTP with Mediterranean Eurasia, as exemplified by Mandragora (Tu etal., 2010); (C) Hengduan-Himalayan forest regions of the QTP showing close biogeographic relationships with Arcto-Tertiary floristic elements in eastern Asia, as exemplified by

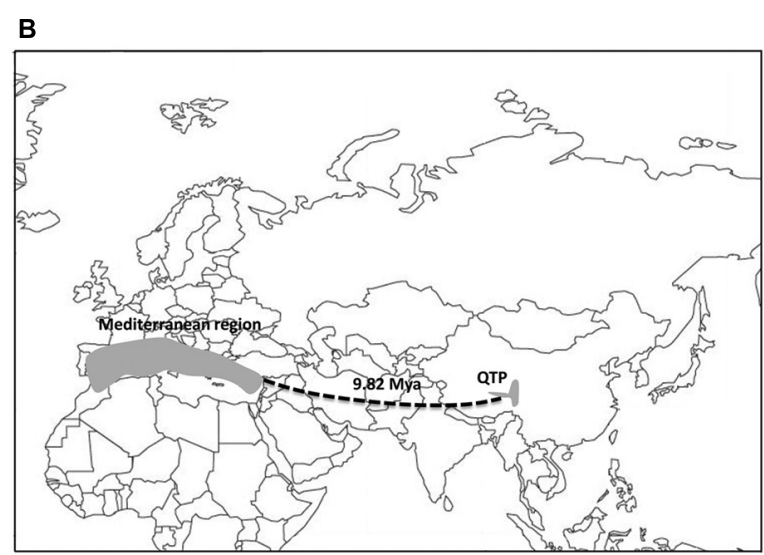

D

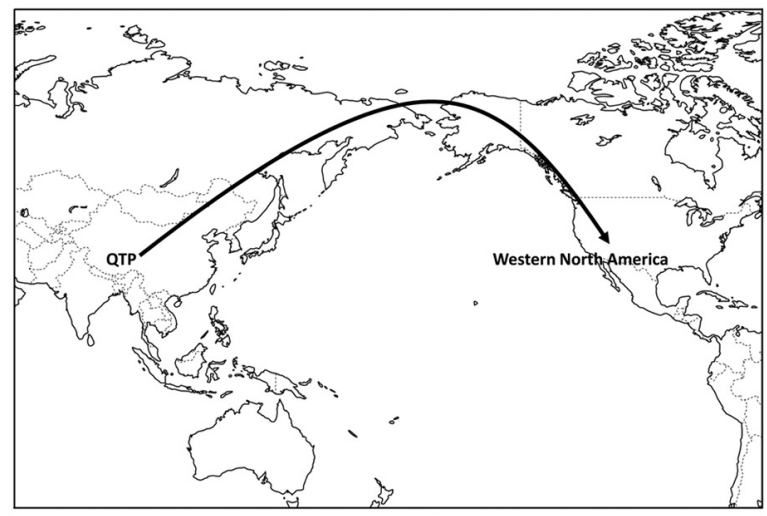

F

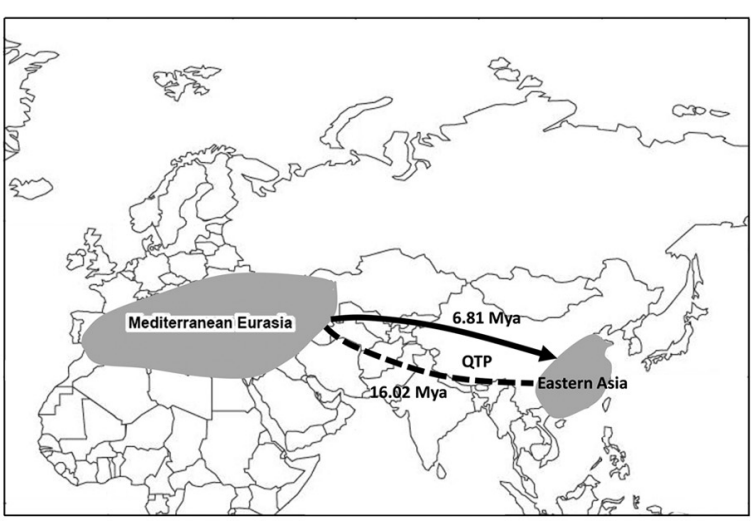

the radiation of Maianthemum on the QTP following the migration from the Sino-Japanese floristic region (Meng etal., 2008); (D) the OTP and western Cordillera forest region of western North American, as shown in Kelloggia (Nie etal., 2005b); (E) migration of the QTP plants from Central Asia, as inferred from Solms-laubachia (Yue etal., 2009); and (F) the QTP as a major biogeographic barrier for plant diversification in Eurasia, as shown by examples of two Mediterranean-eastern Asian disjunctions in Pistacia (Yi etal., 2008; Xie etal., 2014).

\section{CLOSE BIOGEOGRAPHIC CONNECTIONS OF THE OTP WITH THE MEDITERRANEAN EURASIA (Figure 2B), AND/OR NORTH AMERICA}

The Mediterranean regions of Central and West Asia have been suggested to be an important biogeographic source region for plant lineages on the QTP (Sun, 2002a). An excellent example of this disjunct pattern is shown by the genus Mandragora (five species, Solanaceae). Tu etal. (2010) resolved the genus into two clades: one including $M$. officinarum L., M. autumnalis Bertol., and M. turcomanica Mizgir. from the Mediterranean 
region and the other clade consisting of $M$. caulescens C.B. Clarke and M. chinghaiensis K.Z. Kuang \& A.M. Lu from the QTP region (Figure 2B). The origin of this disjunct pattern was interpreted as a result of the interruption of a once more continuous distribution before the uplift of the QTP (Sun, 2002a). The uplift of the QTP was mainly in the Miocene (Harrison et al., 1992) and is the major late Tertiary geologic event in Eurasia. The age of the disjunction in the mandrakes was estimated to be $9.82 \mathrm{Ma}$ [95\% highest posterior density (HPD): 4.40 $16.18 \mathrm{Ma}]$, consistent with a Miocene vicariance hypothesis ( $\mathrm{Tu}$ et al., 2010).

Sun et al. (2001) explored the biogeographic relationships of Helleborus L. (ca. 16 species, Ranunculaceae). They found that species of the large section Helleborastrum Spach mostly from southern Europe and the Mediterranean region formed a clade with the monotypic section Dicarpon Ulbrich consisting of $H$. thibetanus Franch. from the QTP. Using a general molecular clock, the divergence of this disjunction was dated to be $22.96 \mathrm{Ma}$ in the early Miocene. The study provides support of the vicariance hypothesis of an earlier more continuous Tethyan distribution of Helleborus across Eurasia (Wu, 1988). Because the dispersal agents of Helleborus seeds are normally ants, a long distance-dispersal scenario was considered unlikely.

The genus Coriaria Niss. ex L. (Coriariaceae) is morphologically highly variable with 5-20 species recognized by various authors (see Good, 1930; Yokoyama et al., 2000). The single Mediterranean species C. myrtifolia L. forms a clade with the Himalayan C. nepalensis Wall. and C. terminalis Hemsl. on the QTP. This QTP-Mediterranean disjunct clade is then sister to C. japonica A. Gray-C. intermedia Matsum. clade of eastern to SE Asia. Yokoyama et al. (2000) suggested the migration of Coriaria in the direction from Asia to the Mediterranean region and the climatic changes associated with the glaciation and drying in the Cenozoic as the explanation of this Mediterranean-Asian disjunction.

Subgenus Amerallium Traub of the large genus Allium L. (Amaryllidaceae) shows an early vicariance between the QTP and the Mediterranean region (Li et al., 2010a). This Eurasian clade is then sister to the clade of the North American Amerallium taxa. Eastern Asia was inferred to be the most likely ancestral area of the Amerallium clade.

Ephedra L. has been suggested to have originated in the Mediterranean Eurasia (MEA; Ickert-Bond et al., 2009). It then diversified in Asia and the New World with two distinct lineages on the QTP (the southern QTP lineage and the eastern QTP lineage) dated to the middle or late Miocene (Qin et al., 2013; also see Ickert-Bond et al., 2009).

Juniperus L. is a coniferous genus with 67 recognized species and is major component of arid and semi-arid tree/shrub ecosystems in the Northern Hemisphere (Adams, 2008). The genus is monophyletic and is classified into three monophyletic sections: sect. Caryocedrus Endl. (one species in the Mediterranean), sect. Juniperus (nine species in eastern Asia and the Mediterranean plus one circumboreal species J. communis L., and sect. Sabina Spach (56 species distributed in southwestern North America, Asia, and the Mediterranean region, extending to Africa and the Canary Islands). The most comprehensive phylogenetic and biogeographic study of Juniperus was by Mao et al. (2010), who sampled 51 of the 67 recognized species and employed nine cpDNA markers. Most QTP species of Juniperus belong to sect. Sabina. Mao et al. (2010) showed that sect. Sabina has five clades. Clade I contains Juniperus pseudosabina Fisch. \& C.A.Mey. from Central Asia (Xinjiang, China) plus all Himalayan/QTP alpine species except J. microsperma (W.C.Cheng \& L.K.Fu) R.P.Adams (in clade III) and J. gaussenii Cheng. Clade II comprises the serrateleaved junipers of North America and is sister to clade I. Clade III includes the smooth-leaved American species, the Eurasian J. sabina L., the middle Asian J. semiglobosa Regel, and the QTP endemic J. microsperma. Clade IV comprised the J. chinensis L. complex (including the QTP species J. gaussenii) from eastern Asia, J. thurifera L. from Europe, J. excelsa Pursh from the eastern Mediterranean, J. polycarpos K.Koch (from west Himalaya to Caucasus) and J. procera Hochst. ex Endl. (eastern Africa and southern Arabia). Clade $\mathrm{V}$ contained only the Mediterranean J. phoenicea Pall. The ancestral area of Juniperus is in Eurasia, but could be Europe, Asia, or a combination of these two. The phylogeny of Juniperus clearly indicates the close biogeographic relationship of the QTP with Central Asia, as well as with North America in this semi-desert xeric group and supports the Madrean-Tethyan biogeographic connection (Wen and Ickert-Bond, 2009).

\section{HENGDUAN-HIMALAYAN FOREST REGIONS OF THE OTP SHOWING CLOSE BIOGEOGRAPHIC RELATIONSHIPS WITH ARCTO-TERTIARY FLORISTIC ELEMENTS IN EASTERN ASIA AND EASTERN NORTH AMERICA (Figure 2C)}

Recent phylogenetic evidence from various plant lineages supports the view that the Hengduan-Himalayan forest regions of the QTP contain many floristic elements originated from the Arcto-Tertiary flora as well as preserved some unique relict taxa (Wen etal., 1996; Wen, 1999; Sun, 2002b; Xiang et al., 2004). The Arcto-Tertiary floristic elements have been well preserved in eastern Asia (especially in the Sino-Japanese floristic region) as well as eastern North America (Wen, 1998, 1999, 2001; Wen et al., 2010; Harris etal., 2013). Below we briefly discuss a few examples of the QTP plants showing the Arcto-Tertiary floristic affinities. Analyses of large genera such as Rhododendron with adequate sampling from the QTP are still lacking. Some groups, e.g., Angelica L., show a particularly complex biogeographic history (Liao etal., 2012; also see Feng etal., 2009).

Maianthemum (Asparagaceae) consists of ca. 35 species widely distributed in the Northern Hemisphere. The HengduanHimalayan regions represent a major center of diversity for the genus with 13 species. Most Maianthemum species from the Hengduan-Himalayan regions form a well-supported clade nested within several basal grades including species from northeastern Asia and the New World (Meng et al., 2008). The phylogenetic and biogeographic analyses suggest a most likely New World origin and a north-to-south migration within eastern Asia. Species of Maianthemum radiated in the Hengduan-Himalayan regions of the QTP within the last $2 \mathrm{Ma}$, as estimated by Meng et al. (2008), supporting the QTP as a speciation pump for such an Arcto-Tertiary group. The QTP lineage shows a close affinity with 
the Sino-Japanese elements of the genus, especially those from Central to SW China.

Panax L. (the ginseng genus, Araliaceae) consists of about 15-18 species with two from eastern North America and the remaining from eastern Asia spanning from Japan to the Hengduan Mountains and the eastern Himalaya. Molecular phylogenetic results (Lee and Wen, 2004; Zuo et al., 2011) showed a large clade of Panax taxa from the Hengduan-Himalayan region as well as the warm temperate to subtropical areas of the Sino-Japanese region (the $P$. bippinatifidus Seem. superspecies complex). In Panax, the Hengduan-Himalayan region is found to be an active diversification center with recently differentiating taxa, as well as a refugium for some unique and early diverged species (e.g., P. pseudoginseng Wall.). A similar pattern between the taxa from the Hengduan-Himalayan region and the Sino-Japanese region has been recorded in Aralia L. sect. Aralia (Wen etal., 1998; Wen, 2011), with recently diversified species (e.g., A. apioides Hand.-Mazz. and A. atropurpurea Franch.) in the Hengduan Mountains and some early diverged taxa (e.g., $A$. cachemirica Decne. and A. tibetana G. Hoo) in the Himalayan Mountains.

Astilbe (Saxifragaceae) consists of about 20 species with the center of diversity clearly in the Sino-Japanese floristic region with only two species found in the Himalayan-Hengduan regions of the QTP, and one species in eastern North America (Pan, 1995). The phylogenetic and biogeographic analyses of the genus (Kim etal., 2009; Zhu etal., 2013) support three major clades, a clade centered in the northern part of the SinoJapanese region, a clade centered in the central and southern part of the Sino-Japanese region, and a clade of $A$. rivularis Buch.-Ham. ex D.Don primarily distributed in the HimalayanHengduan regions of the QTP extending to SE Asia. The early divergence of $A$. rivularis in the mid-Miocene and the relatively basal position of this widespread species suggest that the Himalayan-Hengduan regions of the QTP served as a refugium for Astilbe evolution in the mid Tertiary. The QTP A. rivularis is also suggested to be sister to the eastern North American relict species A. biternata (Vent.) Britton. The other QTP species A. rubra Hook.f. \& Thoms. dispersed into southern QTP in the late Miocene or early Pliocene from the Sino-Japanese region.

Triosteum L. (Caprifoliaceae) is a small genus of six species with three in eastern Asia and three in eastern North America (Gould and Donoghue, 2000). Triosteum himalayanum Wall. of the QTP was found to be sister to T. pinnatifidum Maxim. from the Sino-Japanese region. The three North American species formed a clade sister to the T. himalayanum-T. pinnatifidum clade. Triosteum sinuatum Maxim. from Central Japan and NE China was the first diverged species of the genus. The QTP species Triosteum himalayanum thus occupies a relatively advanced position within Triosteum.

The genus Podophyllum L. (Berberidaceae) consists of two intercontinental disjunct species: $P$. peltatum $\mathrm{L}$. from eastern North America and P. hexandrum Royle from the HimalayanHengduan Mountains (Liu et al., 2002b), with the latter species sometimes recognized as its own genus Sinopodophyllum T.S. Ying (Li et al., 2011). The monophyly of this disjunct genus of two species has been supported, and Podophyllum is then sister to the genus Dysosma Woodson native to the Sino-Japanese region to South China and neighboring area of North Vietnam (Wang etal., 2007a). The relationships in the PodophyllumDysosma-Diphylleia clade show a close biogeographic relationship among the forest regions of the Himalayan-Hengduan Mountains, the Sino-Japanese floristic region, and eastern North America. The wide disjunction in Podophyllum likely represents a relict distribution dating back to the late Miocene (Wang et al., 2007a).

Even though the eastern Asian-North American biogeographic disjunctions have attracted many research interests in the last 15 years (see review by Wen et al., 2010), the QTP taxa have often not been incorporated in the biogeographic analyses of this classical biogeographic pattern, or the discussions often did not elaborate on the biogeographic assembly within eastern Asia or Asia overall. Future studies clearly need to place the QTP taxa into the perspectives of Arcto-Tertiary plant biogeography.

\section{THE OTP AND WESTERN CORDILLERA FOREST REGION OF WESTERN NORTH AMERICA (Figure 2D)}

The alpine flora of the QTP occasionally shows biogeographic affinities with the forest elements of the western Cordillera of North America. The genus Kelloggia Torr. ex Hook.f. (Rubiaceae) has two species: K. chinensis Franch. from the Hengduan Mountains and K. galioides Torrey from the western United States. Ecologically K. chinensis occurs in alpine meadows or open places or shrublands along the stream of high mountains (about 3000 masl), whereas K. galioides grows in open places in coniferous forests (1100-3000 masl), sometimes among rocks or along streams. The biogeographic and dating analyses by Nie et al. (2005b) suggest that the current intercontinental disjunct distribution of Kelloggia may be best explained to be via a long-distance dispersal from Asia into western North America after the uplift of the Himalayan Mountains and the western Cordillera of North America in the late Miocene.

The QTP harbors high diversity of conifers (Ran et al., 2006). The most extensively analyzed conifer group is the spruce genus Picea A.Dietr. (ca. 35 species), which often occupy forest habitats (also see Meng et al., 2007; Li et al., 2010b, 2013a; Du et al., 2011; Zou et al., 2012). The regions of highest Picea diversity are the western Cordillera of North America and the QTP. The most recent phylogenetic analyses of the genus using mitochondrial, plastid, and nuclear data (Lockwood et al., 2013) suggest that the 9 or 10 Picea species of the QTP region formed a major clade, with one western Cordillera species in North America ( $P$. breweriana S.Watson) and one narrowly distributed species from Taiwan $(P$. morrisonicola Hayata). The QTP clade of the 9-10 species was estimated to have diverged around 19.8 Ma. The ancestral area of Picea has been highly debated (Ran et al., 2006; Bouillé et al., 2011; Lockwood et al., 2013). If we accept the Asian origin hypothesis (Wright, 1955; Lockwood et al., 2013), the diversification of the large QTP clade may be interpreted as having a QTP origin with one dispersal into western North America and another dispersal into Taiwan in the early Miocene. Nevertheless, the phylogenetic position of the western North American Picea breweriana has been controversial and it may represent a relict lineage (Lockwood et al., 2013). 


\section{MIGRATIONS/DISPERSALS FROM CENTRAL ASIA INTO THE OTP (Figure 2E)}

Phylogenetic evidence supports the Central Asian origin with subsequent diversification on the QTP in several groups. This pattern is still poorly known and needs to be further explored. The extensive molecular data of Solms-laubachia Muschl. (Brassicaceae) suggest that the Hengduan Mountain endemics were embedded in a paraphyletic grade of species from Central Asia and the western Himalayas (Yue et al., 2009). The genus was hypothesized to have originated in Central Asia in the Pliocene, and subsequently migrated eastward into the Hengduan Mountains, the eastern border of the QTP. This relatively young group colonized sky-island, alpine scree-slope habitats that may have provided novel ecological opportunity and accelerated speciation, becoming quickly established in the Hengduan Mountains, the present center of diversity for the genus.

Incarvillea Juss. (Bignoniaceae) is composed of 16 species classified into four subgenera with the Himalayan and Hengduan Mountains of the QTP as the current center of diversity and a few species in Central Asia and Mongolia (Grierson, 1961). The earliest diverged taxa are endemic to Central Asia, and the most derived group, subgenus Pteroscleris Baillon, is distributed in the eastern Himalaya and the Hengduan Mountains (Chen et al., 2005). Chen et al. (2005) suggested the dispersal of Incarvillea from Central Asia to the QTP prior to the Miocene, as well as a recent radiation on the QTP, perhaps related to the uplift of the Himalayan-Hengduan massifs.

Myricaria Desv. is a small genus of eleven species, mostly distributed on the QTP and adjacent regions. Wang et al. (2009b) suggested a Himalayan origin of the genus. Recently Chen (2013) re-evaluated the ancestral distribution of the genus, and suggested eastern Asia (the QTP) as the ancestral origin of the genus, and the "out of eastern Asia" episodes only happened after drastic uplifts of the QTP at $5 \mathrm{Ma}$; yet based on their results, the most basally diverged species Myricaria elegans Royle, M. prostrata Hook.f. \& Thomson ex Benth. \& Hook.f. and M. pulcherrima Batalin, as well as the outgroup Tamarix are mainly distributed in the western Himalaya or Xinjiang (NW China) and adjacent regions such as Kashmir and West Pakistan (Wang et al., 2006), where the flora is part of that of Central Asia, rather than eastern Asia (the QTP). The other clades on the phylogenetic tree represented younger evolutionary derivatives mostly on or outside the QTP. Myricaria is thus argued here to have originated from Central Asia, and it then migrated into the QTP and the adjacent regions following its origin.

\section{THE OTP AS A MAJOR BIOGEOGRAPHIC BARRIER FOR PLANT DIVERSIFICATION IN EURASIA}

The eastern Asian-Mediterranean Tethyan biogeographic disjunction (Thompson, 1999; Sun and Li, 2003; Tu et al., 2010; Wan et al., 2013) was largely attributed to be extinctions in the Asian interior during the Miocene (Sun, 2002a; Qiao et al., 2007). The Pliocene climatic changes have been suggested to be a more plausible explanation for more recent disjunctions between Europe and Asia (Fiz-Palacios et al., 2010; Tu et al., 2010; Carlson et al., 2012). The genus Pistacia represents an example of a widespread ancestral area of the Old World clade of Pistacia in MEA and eastern Asia (Yi et al., 2008; Xie et al., 2014). Two independent eastern Asian-MEA disjunction events were inferred within the clade of Old World species. The divergence between the eastern Asian P. weinmannifolia J.Poiss. ex Franch.-P. cucphuongensis T.D.Dai clade and the clade of the remaining Old World species was estimated to be 16.02 mya (95\% HPD: 10.90-23.41 mya) at the boundary of Early and Middle Miocene. The timing of this divergence was consistent with the recent major uplifts of the QTP between the early Miocene to the Pleistocene (Harrison et al., 1992; Guo et al., 2002; Spicer et al., 2003). The second disjunction was between Pistacia chinensis Bunge and the P. integerrima J.L.Stewart-P. palaestina Boiss. $-P$. terebinthus Mill. clade of MEA. Pistacia chinensis from eastern Asia is nested within the clade of MEA species. One dispersal event from MEA to eastern Asia was inferred to account for the distribution of $P$. chinensis. This dispersal event was suggested to have occurred during the late Miocene (6.81 mya, 95\% HPD: 3.59-10.20 mya). Migration between Europe and Asia has been hypothesized to be primarily in an east-west direction (Tiffney and Manchester, 2001), which has been supported by molecular evidence in Rhus L. (Yi et al., 2004). Yet Scabiosa L. was inferred to have migrated from west to east (Carlson et al., 2012). The biogeographic diversification of Pistacia chinensis and its close relatives represents another example of such a west-to-east migration direction across Eurasia.

Scabiosa (Dipsacaceae) exhibits an unusual Old World disjunction in Asia (12 species), Europe (primarily in the Mediterranean Basin, ca. 14 taxa), and eastern and southern Africa (ca. eight species). Scabiosa was inferred to have originated in the middle to late Miocene in Mediterranean Europe, followed by independent migrations into Asia and Africa (Carlson et al., 2012). The split between Europe and Asia in Scabiosa was inferred to be 2.3-6.6 Ma. Even though Carlson et al. (2012) did not rule out the vicariance hypothesis, the Pliocene climate fluctuations were proposed to be a more likely explanation for this disjunction, as is consistent with studies on other plant groups exhibiting more recent disjunctions between Europe and Asia (see Fiz-Palacios et al., 2010; Tu et al., 2010).

The high mountains in the QTP and adjacent areas apparently have served as biogeographic barriers for some plant groups. For example, a clade including Scapiarabis M.Koch, R.Karl, D.A.German \& Al-Shehbaz, Botschantzevia Nabiev, Arcyosperma O.E.Schulz, Parryodes Jafri, and Borodiniopsis D.A.German, M.Koch, R.Karl \& Al-Shehbaz of tribe Arabeae of Brassicaceae forms a circle around the Asian high mountain system, which is interrupted and separated by genetically distinct members of the sister clade that includes Baimashania Al-Shehbaz, Pseudodraba Al-Shehbaz, D.A.German \& M.Koch, and Sinoarabis R.Karl, D.A.German, M.Koch \& Al-Shehbaz (Koch et al., 2012). The unique biogeographic circle predates the Pleistocene with these genera dated to be of Pliocene origin.

\section{THE OTP AND THE SOUTHERN HEMISPHERE}

Most taxa endemic to the QTP have been hypothesized to have originated in situ or from areas in the Northern Hemisphere, as discussed above. Nannoglottis Maxim. (Asteraceae), with ca. eight species endemic to the QTP, is however found to be monophyletic and supported as an isolated genus as the first diverged 
lineage of the tribe Astereae, which has a Southern Hemisphere origin (Liu et al., 2002a; Brouillet et al., 2009; V. A. Funk, personal communication). Long-distance dispersal using SE Asia as a steppingstone from Southern Hemisphere to the QTP was suggested the most likely explanation for this unusual biogeographic link of Nannoglottis with the Southern Hemisphere (Liu et al., 2002a). The molecular phylogeny of the genus further identifies two distinct clades, the "alpine shrub" and the "coniferous forest" clades, with their divergence estimated at ca. 3.4 Ma when the plateau began its first large-scale uplift and the coniferous vegetation began to appear. Most species of the "coniferous forest" clade of the genus are estimated to have originated from 1.02 to 1.94 Ma, when the second and third uplifts of the QTP occurred, the climate oscillated and the habitats were changed drastically. The genus Koenigia has most species on the QTP and the adjacent areas; yet one species $K$. islandica was widespread in the arctic and alpine areas of the Northern Hemisphere as well as southern South America (Hedberg, 1997). This South American distribution of $K$. islandica is apparently due to a recent long-distance dispersal from the Northern Hemisphere, most likely not directly from the QTP (Fan et al., 2013b). Biogeographic connections between the QTP and the Southern Hemisphere are rare and need to be explored in future studies.

\section{PROSPECTUS}

Allopatric differentiations (vicariance) have been supported to be important in the plant diversification on the QTP. Species radiations on the QTP can provide unique insights into speciation, species interactions and diversifications, and morphological innovations, due to the relative recent geologic history of the QTP and its extraordinarily rich biodiversity. Little is still known on the patterns associated with the evolutionary radiations through integrative studies of phylogeny, morphological innovations, geography, diversification rates, ecology, and cytology of the QTP plants. Also insights into the patterns and processes of species diversifications have been hampered by the often poorly resolved species phylogenies. Multilocus approaches using many genes via conventional Sanger sequencing should remain as a useful approach for the near future. Nevertheless, the next-generation sequencing (NGS) approaches now have shown great potential for efficiently sampling entire genomes of plant species for phylogenetically informative variation. NGS approaches such as restriction-site associated DNA sequencing (RADseq; Miller et al., 2007; Baird et al., 2008; Emerson et al., 2010; Peterson et al., 2012), or genotyping-by-sequencing (GBS; Elshire et al., 2011) allow the regions adjacent to restriction sites to be surveyed with deep coverage. The RADseq data have been recently utilized to explore the phylogenetic relationships of recently diverged taxa or radiations (Eaton and Ree, 2013; Wagner et al., 2013) and they can be employed to study the species diversifications on the QTP. Sequences of whole plastomes or a large number of rapidly evolving regions of plastomes have been obtained via NGS to resolve rapid radiations (e.g., Fior et al., 2013; Li et al., 2013b). Other NGS approaches such as RNA-Seq (Wang et al., 2009d) may provide insights into the developmental mechanisms of some of the fascinating morphological innovations associated with evolutionary radiations. The biogeographic relationships of the QTP with other regions of the Northern Hemisphere need to be explored more extensively to better understand the role of the QTP in the evolutionary diversification of plants (also see Lexer et al., 2013). Integrative multidimensional analyses of phylogeny, morphological innovations, geography, ecology, development, species interactions and diversifications, and geology (Wen et al., 2013) are needed and should shed insights into the patterns of evolutionary assembly and radiations in this fascinating region.

\section{ACKNOWLEDGMENTS}

The study was supported by grants from the John D. and Catherine T. MacArthur Foundation, and the Endowment Grant Program of the Smithsonian Institution to Jun Wen and Key project NSFCYunnan United fund (U136601) to Hang Sun. We thank Federico Luebert and Ludo Muller for the invitation to contribute to the special volume, Vicki Funk for helpful discussions on Asteraceae biogeography, Sue Lutz for assistance in preparing the figures, and Jian-Quan Liu and Stefanie Ickert-Bond for their most helpful suggestions.

\section{REFERENCES}

Adams, R. P. (2008). Junipers of the World: the Genus Juniperus, 2nd Edn. Vancouver, BC: Trafford Publishing.

An, Z. S., Kutzbach, J. E., Prell, W. L., and Port, S. C. (2001). Evolution of Asian monsoons and phased uplift of the Himalayan-Tibetan Plateau since late Miocene times. Nature 411, 62-66. doi: 10.1038/35075035

Baird, N. A., Etter, P. D., Atwood, T. S., Currey, M. C., Shiver, A. L., Lewis, Z. A., et al. (2008). Rapid SNP discovery and genetic mapping using sequenced RAD markers. PLoS ONE 3:e3376. doi: 10.1371/journal.pone.0003376

Blöch, C., Dickoré, W. B., Samuel, R., and Stuessy, T. (2010). Molecular phylogeny of the Edelweiss (Leontopodium, Asteraceae-Gnaphalieae). Edinb. J. Bot. 67, 235264. doi: 10.1017/S0960428610000065

Bouillé, M., Senneville, S., and Bousquet, J. (2011). Discordant mtDNA and cpDNA phylogenies indicate geographic speciation and reticulation as driving factors for the diversification of the genus Picea. Tree Genet. Genomes 7, 469-484. doi: 10.1007/s11295-010-0349-z

Brochmann, C., Brysting, A. K., Alsos, I. G., Borgen, L., Grundt, H. H., Scheen, A.-C., et al. (2004). Polyploidy in arctic plants. Biol. J. Linn. Soc. 82, 521-536. doi: 10.1111/j.1095-8312.2004.00337.x

Brouillet, L., Lowrey, T. K., Urbatsch, L., Karaman-Castro, V., Sancho, G., Wagstaff, S., et al. (2009). "Astereae”, in Systematics, Evolution, and Biogeography of Compositae, eds V. A. Funk, A. Susanna, T. F. Stuessy, and R. J. Bayer (Vienna: IAPT), 589-630.

Carlson, S. E., Linder, P. H., and Donoghue, M. J. (2012). The historical biogeography of Scabiosa (Dipsacaceae): implications for Old World plant disjunctions. J. Biogeogr. 39, 1086-1100. doi: 10.1111/j.1365-2699.2011.02669.x

Carolan, J., Hook, I., Chase, M., Kadereit, J. W., and Hodkinson, T. R. (2006). Phylogenetics of Papaver and related genera based on DNA sequences from ITS nuclear ribosomal DNA and plastid trnL intron and trnL-F intergenic spacers. Ann. Bot. 98, 141-155. doi: 10.1093/aob/mcl079

Chamberlain, D. F. (1982). A revision of Rhododendron II. Subgenus Hymenanthes. Notes R. Bot. Gard. Edinb. 39, 209-486.

Chen, G., Sun, W. B., and Sun, H. (2007). Ploidy variation in Buddleja L. (Buddlejaceae) in the Sino-Himalayan region and its biogeographical implications. Bot. J. Linn. Soc. 154, 305-312. doi: 10.1111/j.1095-8339.2007.00650.x

Chen, S., Guan, K., Zhou, Z., Olmstead, R., and Cronk, Q. (2005). Molecular phylogeny of Incarvillea (Bignoniaceae) based on ITS and trnL-F sequences. Am J. Bot. 92, 625-633. doi: 10.3732/ajb.92.4.625

Chen, S. T., Xing, Y. W., Su, T., Zhou, Z. K., Dilcher, E. D., and Soltis, D. (2012). Phylogeographic analysis reveals significant spatial genetic structure of Incarvillea sinensis as a product of mountain building. BMC Plant Biol. 12:58. doi 10.1186/1471-2229-12-58

Chen, S. Y., Wu, G. L., Zhang, D. J., Gao, Q. B., Duan, Y. Z., Zhang, F. Q., et al. (2008). Potential refugium on the Qinghai-Tibet Plateau revealed by the chloroplast DNA 
phylogeography of the alpine species Metagentiana striata (Gentianaceae). Bot. J. Linn. Soc. 157, 125-140. doi: 10.1111/j.1095-8339.2008.00785.x

Chen, Y. H. (2013). A revisited study on phylogeography and phylogenetic diversity of Myricaria (Tamaricaceae) J. Ecosyst. Ecogr. 3, 132. doi: 10.4172/2157 7625.1000132

Coleman, M., and Hodges, K. (1995). Evidence for Tibetan Plateau uplift before $14 \mathrm{Myr}$ age from new minimum estimate for east-west extension. Nature 374, 49-52. doi: 10.1038/374049a0

Cun, Y. Z., and Wang, X. Q. (2010). Plant recolonization in the Himalaya from the southeastern Qinghai-Tibetan Plateau: geographical isolation contributed to high population differentiation. Mol. Phylogenet. Evol. 56, 972-982. doi: 10.1016/j.ympev.2010.05.007

Du, F. K., Peng, X. L., Liu, J. Q., Lascoux, M., Hu, F. S., and Petit, R. (2011). Direction and extent of organelle DNA introgression between two spruce species in the Qinghai-Tibetan Plateau. New Phytol. 192, 1024-1033. doi: 10.1111/j.14698137.2011.03853.x

Duan, Y. W., Zhang, T. F., He, Y. P., and Liu, J. Q. (2009). Insect and wind pollination of an alpine biennial Aconitum gymnandrum (Ranunculaceae). Plant Biol. 11, 796-802. doi: 10.1111/j.1438-8677.2009.00195.x

Duan, Y. W., Zhang, T. F., and Liu, J. Q. (2007). Interannual fluctuations in floral longevity, pollinator visitation and pollination limitation of an alpine plan (Gentiana straminea Maxim., Gentianaceae) at two altitudes in the QinghaiTibetan Plateau. Plant Syst. Evol. 267, 255-265. doi: 10.1007/s00606-0070553-y

Eaton, D. A. R., Fenster, C. B., Hereford, J., Huang, S. Q., and Ree, R. H. (2012). Floral diversity and community structure in Pedicularis (Orobanchaceae). Ecology 93, S182-S194. doi: 10.1890/11-0501.1

Eaton, D. A. R., and Ree, R. H. (2013). Inferring phylogeny and introgression using RADseq data: an example from flowering plants (Pedicularis: Orobanchaceae) Syst. Biol. 62, 689-706. doi: 10.1093/sysbio/syt032

Elshire, R. J., Glaubitz, J. C., Sun, Q., Poland, J. A., Kawamoto, K., Buckler, E. S., et al. (2011). A robust, simple genotyping-by-sequencing (GBS) approach for high diversity species. PLoS ONE 6:e19379. doi: 10.1371/journal.pone.0019379 doi: 10.1371/journal.pone.0019379

Emerson, K. J., Merz, C. R., Catchen, J. M., Hohenlohe, P. A., Cresko, W. A. Bradshaw W. E., et al. (2010). Resolving postglacial phylogeography using highthroughput sequencing. Proc. Nat. Acad. Sci. U.S.A. 107, 16196-16200. doi: $10.1073 /$ pnas. 1006538107

Fan, D.-M., Yue, J.-P., Nie, Z.-L., Li, Z.-M., Comes, H. P., and Sun, H. (2013a). Phylogeography of Sophora davidii (Leguminosae) across the "Tanaka-Kaiyong Line", and important phytogeographic boundary in Southwest China. Mol. Ecol. 22, 4270-4288. doi: 10.1111/mec.12388

Fan, D.-M., Chen, J.-H., Meng, Y., Wen, J., Huang, J. L., and Yang, Y.-P. (2013b). Molecular phylogeny of Koenigia L. (Polygonaceae: Persicarieae): implications for classification, character evolution and biogeography. Mol. Phylogenet. Evol. 69, 1093-1100. doi: 10.1016/j.ympev.2013. 08.018

Fang, R. Z., and Min, T. L. (1995). The floristic study on the genus Rhododendron. Acta Bot. Yunnan. 17, 359-379.

Feng, T., Downie, S. R., Yu, Y., Zhang, X. M., Chen, W. W., He, X. J., et al. (2009). Molecular systematics of Angelica and allied genera (Apiaceae) from the Hengduan Mountains of China based on nrDNA ITS sequences: phylogenetic affinities and biogeographic implications. J. Plant Res. 122, 403-414. doi: 10.1007/s10265-009-0238-4

Fior, S., Li, M., Oxelman, B., Viola, R., Hodges, S. A., Ometto, L., et al. (2013). Spatiotemporal reconstruction of the Aquilegia rapid radiation through nextgeneration sequencing of rapidly evolving cpDNA regions. New Phytol. 198, 579592. doi: 10.1111/nph.12163

Fiz-Palacios, O., Vargas, P., Vila, R., Papadopulos, A. S. T., and Aldasoro, J. J. (2010) The uneven phylogeny and biogeography of Erodium (Geraniaceae): radiations in the Mediterranean and recent recurrent intercontinental colonization. Ann. Bot. 106, 871-884. doi: 10.1093/aob/mcq184

Friesen, N., Fritsch, R. M., Pollner, S., and Blattner, F. R. (2000). Molecular and morphological evidence for an origin of the aberrant genus Milula within Himalayan species of Allium (Alliaceae). Mol. Phylogenet. Evol. 17, 209-218. doi: 10.1006/mpev.2000.0844

Fu, K. T., and Ohba, H. (2001). "Crassulaceae," in Flora of China, Vol. 8, eds Z. Y. Wu and P. H. Raven (Beijing: Science Press), 202-268.
Fu, S. H., and Fu, K. T. (eds). (1984). “Crassulaceae,” in Vol. 34, Flora Reipublicae Popularis Sinicae, (Beijing: Science Press), 31-220.

Geng, Y., Cram, J., and Zhong, Y. (2009). "Genetic diversity and population structure of alpine plants endemic to Qinghai-Tibetan Plateau, with implications for conservation under global warming," in Genetic Diversity, eds C. L. Mahoney and D. A. Springer (Hauppauge, NY: Nova Science Publishers), 213-228.

Goetsch, L., Eckert, A. J., and Hall, B. D. (2005). The molecular systematics of Rhododendron (Ericaceae): a phylogeny based upon RPB2 gene sequences. Syst. Bot. 30, 616-626. doi: 10.1600/0363644054782170

Good, R. D. O. (1930). The geography of the genus Coriaria. New Phytol. 29, 170-198. doi: 10.1111/j.1469-8137.1930.tb06989.x

Gould, K. R., and Donoghue, M. J. (2000). Phylogeny and biogeography of Triosteum (Caprifoliaceae). Harv. Pap. Bot. 5, 157-166.

Grant, V. (1981). Plant Speciation. New York: Columbia University Press.

Grierson, A. J. C. (1961). A revision of the genus Incarvillea. Notes R. Bot. Gard. Edinb. 23, 303-354.

Guo, Z. T., Ruddiman, W. F., Hao, Q. Z., Wu, H. B., Qiao, Y. S., Zhu, R. X., et al. (2002). Onset of Asian desertification by $22 \mathrm{Myr}$ ago inferred from loess deposits in China. Nature 416, 159-163. doi: 10.1038/416159a

Guo, Z. T., Sun, B., Zhang, Z. S., Peng, S. Z., Xiao, G. Q., Ge, J. Y., et al. (2008). A major reorganization of Asian climate by the early Miocene. Clim. Past 4, 153-174. doi: 10.5194/cp-4-153-2008

Harris, A. J., Wen, J., and Xiang, Q.-Y. (2013). Inferring the biogeographic origins of inter-continental disjunct endemics using a Bayes-DIVA approach. J. Syst. Evol. 51, 117-133. doi: 10.1111/jse.12007

Harrison, T. M., Copland, P., Kidd, W. S. F., and Yin, A. (1992). Raising Tibet. Science 255, 1663-1670. doi: 10.1126/science.255.5052.1663

He, Y. P., Duan, Y. W., Liu, J. Q., and Smith, W. K. (2006). Floral closure in response to temperature and pollination in Gentiana straminea Maxim. (Gentianaceae) an alpine perennial in the Qinghai-Tibetan Plateau. Plant Syst. Evol. 256, 17-33. doi: 10.1007/s00606-005-0345-1

Hedberg, O. (1997). The genus Koenigia L. emend. Hedberg (Polygonaceae). Bot. J. Linn. Soc. 124, 295-330.

Hewitt, G. (2000). The genetic legacy of the Quaternary ice ages. Nature 405, 907913. doi: 10.1038/35016000

Hewitt, G. M. (2004). Genetic consequences of climatic oscillations in the Quaternary. Philos. Trans. R. Soc. Lond. B Biol. Sci. 359, 183-110. doi: 10.1098/rstb.2003.1388

Hong, D. Y., Ge, S., Lammers, T. G., and Klein, L. L. (2011). “Campanulaceae," in Flora of China, Vol. 19, eds Z. Y. Wu, D. Y. Hong, and P. H. Raven (St. Louis: Missouri Botanical Garden Press/Beijing: Science Press), 505-512.

Hong, D. Y., and Ma, L. M. (1991). Systematics of the genus Cyananthus Wall. ex Royle. Acta Phytotaxon. Sin. 29, 25-51.

Hou, Q.-Z., Meng, L.-H., and Yang, H.-L. (2008). Pollination ecology of Gentiana siphonantha (Gentianaceae) and a further comparison with its sympatric species. J. Syst. Evol. 46, 554-562. doi: 10.3724/SP.J.1002.2008.07063

Huang, S. Q., and Shi, X. Q. (2013). Floral isolation in Pedicularis: how do congeners with shared pollinators minimize reproductive interference? New Phytol. 199 858-865. doi: 10.1111/nph.12327

Ickert-Bond, S. M., Rydin, C., and Renner, S. S. (2009). A fossil-calibrated relaxed clock for Ephedra indicates an Oligocene age for the divergence of Asian and New World clades and Miocene dispersal into South America. J. Syst. Evol. 47, 444-456. doi: 10.1111/j.1759-6831.2009.00053.x

Jia, D. R., Abbott, R. J., Liu, T. L., Mao, K. S., Bartish, I. V., and Liu, J. Q. (2012). Out of the Qinghai-Tibet Plateau: evidence for the origin and dispersal of Eurasian temperate plants from a phylogeographic study of Hippophae rhamnoides (Elaeagnaceae). New Phytol. 194, 1123-1133. doi: 10.1111/j.1469-8137.2012.04115.x

Jia, D. R., Liu, T. L., Wang, L. Y., Zhou, D. W., and Liu, J. Q. (2011). Evolutionary history of an alpine shrub Hippophae tibetana (Elaeagnaceae): allopatric divergence and regional expansion. Biol. J. Linn. Soc. 102, 37-50. doi: 10.1111/j.1095-8312.2010.01553.x

Jork, K. B., and Kadereit, J. W. (1995). "Molecular phylogeny of the Old World representatives of Papaveraceae subf. Papaveroideae with special emphasis on the genus Meconopsis Vig. Plant Syst. Evol. 9(Suppl.), 171-180.

Kadereit, J. W., Preston, C. D., and Valtueña, F. J. (2011). Is Welsh poppy, Meconopsis cambrica (L.) Vig. (Papaveraceae), truly a Meconopsis? New J. Bot. 1, $80-87$. 
Kadereit, J. W., Schwarzbach, A. E., and Jork, K. B. (1997). The phylogeny of Papaver s.l. (Papaveraceae): polyphyly or monophyly? Plant Syst. Evol. 204, 75-98. doi: 10.1007/BF00982533

Kim, S. Y., Kim, S. H., Shin, H., and Kim, Y. D. (2009). Molecular phylogeny of Astilbe: implications for phylogeography and morphological evolution. Korean J. Plant Taxon. 39, 35-41.

Kita, Y., Fujikawa, K., Ito, M., Ohba, H., and Kato, M. (2004). Molecular phylogenetic analyses and systematics of the genus Saussurea and related genera (Asteraceae, Cardueae). Taxon 53, 679-690. doi: 10.2307/4135443

Koch, M. A., Karl, R., German, D. A., and Al-Shehbaz, I. A. (2012). Systematics, taxonomy and biogeography of three new Asian genera from the Brassicaceae, tribe Arabideae: an ancient distribution circle around the Asian high mountains. Taxon 61, 955-969.

Kron, K. A. (1997). Phylogenetic relationships of Rhododendroideae (Ericaceae). Am. J. Bot. 84, 973-980. doi: 10.2307/2446288

Lee, C., and Wen, J. (2004). Phylogeny of Panax using chloroplast trnC$\operatorname{trnD}$ intergenic region and the utility of $\operatorname{trnC}-\operatorname{trnD}$ in interspecific studies of plants. Mol. Phylogenet. Evol. 31, 894-903. doi: 10.1016/j.ympev.2003. 10.009

Lexer, C., Mangili, S., Bossolini, E., Forest, F., Stölting, K. N., Pearman, P. B., et al. (2013). 'Next generation' biogeography: towards understanding the drivers of species diversification and persistence. J. Biogeogr. 40, 1013-1022. doi: $10.1111 /$ jbi.12076

Li, B.-S., Zhang, J.-W., Wang, J.-T., and Chen, W.-L. (1985). The alpine cushion vegetation of Xizang. Acta Bot. Sin. 27, 311-317.

Li, G.-D., Kim, C. K., Zha, H. G., Zhou, Z., Nie, Z. L., and Sun, H. (2014). Molecular phylogeny and biogeography of the arctic-alpine genus Lagotis (Plantaginaceae) Taxon (in press).

Li, L., Abbott, R. J., Liu, B. B., Sun, Y. S., Li, L. L., Zou, J. B., et al. (2013a) Pliocene infraspecific divergence and Plio-Pleistocene range expansions within Picea likiangensis (Lijiang spruce), a dominant forest tree of the Qinghai-Tibet Plateau. Mol. Ecol. 22, 5237-5255. doi: 10.1111/mec. 12466

Li, R., Ma, P.-F., Wen, J., and Yi, T.-S. (2013b). Complete sequencing of five Araliaceae chloroplast genomes and the phylogenetic implications. PLoS ONE 8:e78568. doi: 10.1371/journal.pone.0078568.

Li, J. J., Shi, Y. F., and Li, B. Y. (1995). Uplift of the Qinghai-Xizang (Tibet) Plateau and Global Change. Lanzhou: Lanzhou University Press.

Li, Q.-Q., Zhou, S.-D., He, X.-J., Yu, Y., Zhang, Y.-C., and Wei, X.-Q. (2010a) Phylogeny and biogeography of Allium (Amaryllidaceae: Allieae) based on nuclear ribosomal internal transcribed spacer and chloroplast rps16 sequences, focusing on the inclusion of species endemic to China. Ann. Bot. 106, 709-733. doi: $10.1093 / \mathrm{aob} / \mathrm{mcq} 177$

Li, Y., Stocks, M., Hemmila, S., Källman, T., Zhu, H., Zhou, Y., et al. (2010b) Demographic histories of four spruce (Picea) species of the Qinghai-Tibetan Plateau and neighboring areas inferred from multiple nuclear loci. Mol. Biol. Evol. 27, 1001-1014. doi: 10.1093/molbev/msp301

Li, X.-J., Wang, L.-Y., Yang, H.-L., and Liu, J.-Q. (2008). Confirmation of natural hybrids between Gentiana straminea and $G$. siphonantha (Gentianaceae) based on molecular evidence. Front. Biol. Chin. 3, 470-476. doi: 10.1007/s11515-0080076-0

Li, X. W., and Li, J. (1993). A preliminary floristic study on the seed plants from the region of Hengduan Mountains. Acta Bot. Yunnan. 15, 217-231.

Li, Y., Zhai, S.-N., Qiu, Y.-X., Guo, Y.-P., Ge, X.-J., and Comes, H. P. (2011). Glacial survival east and west of the 'Mekong-Salween Divide' in the HimalayaHengduan Mountains region as revealed by AFLPs and cpDNA sequence variation in Sinopodophyllum hexandrum (Berberidaceae). Mol. Phylogenet. Evol. 59, 412 424. doi: 10.1016/j.ympev.2011.01.009

Liao, C.-Y., Downie, S. R., Yu, Y., and He, X.-J. (2012). Historical biogeography of the Angelica group (Apiaceae tribe Selineae) inferred from analyses of nrDNA and cpDNA sequences. J. Syst. Evol. 50, 206-217. doi: 10.1111/j.17596831.2012.00182.X

Ling, Y. (1979). “Anaphalis,” in Flora Reipublicae Popularis Sinicae, Vol. 75, Angiospermae: Dicotyledonae: Compositae (2), Inuleae-Helenieae, ed. Y. Ling (Beijing: Science Press), 141-218.

Lipschitz, S. J. (1979). Genus Saussurea DC. (Asteraceae). Lenipopoli: Lenipopoli Science Press.

Liu, B.-B., Opgenoorth, L., Miehe, G., Zhang, D.-Y., Wan, D.-S., Zhao, C.-M., et al. (2013). Molecular bases for parallel evolution of translucent bracts in an alpine "glasshouse" plant Rheum alexandrae (Polygonaceae). J. Syst. Evol. 51, 134-141. doi: 10.1111/j.1759-6831.2012.00225.x

Liu, J. Q., Chen, Z.-D., and Lu, A.-M. (2000). The phylogenetic relationships of an endemic genus Sinadoxa in the Qinghai-Xizang Plateau: evidence from ITS sequence analysis. Acta Bot. Sin. 42, 656-658.

Liu, J. Q., Gao, T. G., Chen, Z. D., and Lu, A. M. (2002a). Molecular phylogeny and biogeography of the Qinghai-Tibet plateau endemic Nannoglottis (Asteraceae). Mol. Phylogenet. Evol. 23, 307-325. doi: 10.1016/S1055-7903(02)00039-8

Liu, J. Q., Chen, Z. D., and Lu, A. M. (2002b). Molecular evidence for the sister relationship of the eastern Asian-North American intercontinental species pair in the Podophyllum group (Berberidaceae). Bot. Bull. Acad. Sin. 43, 147-154.

Liu, J. Q., Liu, S. W., Ho, T. N., and Lu, A. M. (2001). Karyological studies on the Sino-Himalayan genus, Cremanthodium (Asteraceae: Senecioneae). Bot. J. Linn. Soc. 135, 107-112. doi: 10.1006/bojl.2000.0385

Liu, J. Q., Sun, Y. S., Ge, X. J., Gao, L. M., and Qiu, Y. X. (2012). Phylogeographic studies of plants in China: advances in the past and directions in the future. $J$ Syst. Evol. 50, 267-275. doi: 10.1111/j.1759-6831.2012.00214.x

Liu, J. Q., Wang, Y. J., Wang, A. L., Ohba, H., and Abbott, R. J. (2006). Radiation and diversification within the Ligularia-Cremanthodium-Parasenecio complex (Asteraceae) triggered by uplift of the Qinghai-Tibetan Plateau. Mol. Phylogenet Evol. 38, 31-49. doi: 10.1016/j.ympev.2005.09.010

Liu, R., Wang, A., Tian, X., Wang, D., and Liu, J. Q. (2010). Uniformity of karyotypes in Rheum (Polygonaceae), a species-rich genus in the Qinghai-Tibetan Plateau and adjacent regions. Caryologia 63, 82-90.

Lockwood, J. D., Aleksic, J. M., Zou, J., Wang, J., Liu, J. Q., and Renner, S. M. (2013). A new phylogeny for the genus Picea from plastid, mitochondrial, and nuclear sequences. Mol. Phylogenet. Evol. 69, 717-727. doi: 10.1016/j.ympev.2013.07.004

Löve, A., and Löve, D. (1967). Polyploidy and altitude: Mt. Washington. Biol. Zent. 86(Suppl.), 307-312.

Luo, D., Liu, D., Xu, B., Nie, Z.-L., Sun, H., and Li, Z.-M. (2011). A karyological study of six species of Silene L. (Caryophyllaceae) from the Hengduan Mountains, SW China. Caryologia 64, 10-13.

Ma, X. F., Szmidt, A. E., and Wang, X. R. (2006). Genetic structure and evolutionary history of a diploid hybrid pine Pinus densata inferred from the nucleotide variation at seven gene loci. Mol. Biol. Evol. 23, 807-816. doi: $10.1093 / \mathrm{molbev} / \mathrm{msj} 100$

Macior, L. W., and Sood, S. K. (1991). Pollination ecology of Pedicularis megalantha D. Don (Scrophulariaceae) in the Himachal Himalaya. Plant Species Biol. 6, 75-81. doi: 10.1111/j.1442-1984.1991.tb00212.x

Macior, L. W., and Tang, Y. (1997). A preliminary study of the pollination ecology of Pedicularis in the Chinese Himalaya. Plant Species Biol. 12, 1-7. doi 10.1111/j.1442-1984.1997.tb00150.x

Macior, L. W., Tang, Y., and Zhang, J. C. (2001). Reproductive biology of Pedicularis (Scrophulariaceae) in the Sichuan Himalaya. Plant Species Biol. 16, 83-89. doi: 10.1046/j.1442-1984.2001.00048.x

Mao, K., Hao, G., Liu, J., Adams, R. P., and Milne, R. I. (2010). Diversification and biogeography of Juniperus (Cupressaceae): variable diversification rates and multiple intercontinental dispersals. New Phytol. 188, 254-272. doi 10.1111/j.1469-8137.2010.03351.x

Mayrose, I., Zhan, S. H., Rothfels, C. J., Magnuson-Ford, K., Barker, M. S., Rieseberg, L. H., et al. (2011). Recently formed polyploid plants diversify at lower rates. Science 333, 1257. doi: 10.1126/science. 1207205

Meng, L., Yang, R., Abbott, R. J., Miehe, G., Hu, T., and Liu, J. Q. (2007). Mitochondrial and chloroplast phylogeography of Picea crassifolia Kom. (Pinaceae) in the Qinghai-Tibetan Plateau and adjacent highlands. Mol. Ecol. 16, 4128-4137. doi: 10.1111/j.1365-294X.2007.03459.x

Meng, Y., Nie, Z. L., Sun, H., and Yang, Y. P. (2012). Chromosome numbers and polyploidy in Leontopodium (Asteraceae: Gnaphalieae) from the QinghaiTibet Plateau of SW China. Caryologia 65, 87-93. doi: 10.1080/00087114.2012. 709779

Meng, Y., Sun, H., Yang, Y. P., and Nie, Z. L. (2010). Polyploidy and new chromosome counts in Anaphalis (Asteraceae: Gnaphalieae) from the Qinghai-Tibet Plateau of China. J. Syst. Evol. 48, 58-64. doi: 10.1111/j.1759-6831.2009.00061.x

Meng, Y., Wen, J., Nie, Z. L., Sun, H., and Yang, Y. P. (2008). Phylogeny and biogeographic diversification of Maianthemum (Ruscaceae: Polygonatae). Mol Phylogenet. Evol. 49, 424-434. doi: 10.1016/j.ympev.2008.07.017

Miller, M. R., Dunham, J. P., Amores, A., Cresko, W. A., and Johnson, E. A (2007). Rapid and cost-effective polymorphism identification and genotyping 
using restriction site associated DNA (RAD) markers. Genome Res. 17, 240-248. doi: 10.1101/gr.5681207

Milne, R. I. (2004). Phylogeny and biogeography of Rhododendron subsection Pon tica, a group with a Tertiary relict distribution. Mol. Phylogenet. Evol. 33, 389-401. doi: 10.1016/j.ympev.2004.06.009

Milne, R. I., Davies, C., Prickett, R., Inns, L. H., and Chamberlain, D. F. (2010) Phylogeny of Rhododendron subgenus Hymenanthes based on chloroplast DNA markers: between-lineage hybridisation during adaptive radiation? Plant Syst. Evol. 285, 233-244. doi: 10.1007/s00606-010-0269-2

Nie, Z. L., Funk, V., Sun, H., Deng, T., Meng, Y., and Wen, J. (2013). Molecular phylogeny of Anaphalis (Asteraceae, Gnaphalieae) with biogeographic implications in the Northern Hemisphere. J. Plant Res. 126, 17-32. doi 10.1007/s10265-012-0506-6

Nie, Z. L., Gu, Z. J., and Sun, H. (2002). Cytological study of Tibetia (Fabaceae) in the Hengduan Mountains region, China. J. Plant Res. 115, 17-22. doi: $10.1007 /$ s102650200003

Nie, Z. L., Wen, J., Gu, Z. J., Boufford, D. E., and Sun, H. (2005a). Polyploidy in the flora of the Hengduan Mountains hotspot, southwestern China. Ann. Missour Bot. Gard. 92, 275-306.

Nie, Z. L., Wen, J., Sun, H., and Bartholomew, B. (2005b). Monophyly of Kelloggia Torrey ex Benth. (Rubiaceae) and evolution of its intercontinental disjunction between western North America and eastern Asia. Am. J. Bot. 92, 642-652. doi: 10.3732/ajb.92.4.642

Niu, Y., Yang, Y., Zhang, Z. Q., Li, Z. M., and Sun, H. (2011). Floral closure induced by pollination in gynodioecious Cyananthus delavayi (Campanulaceae): effects of pollen load and type, floral morph and fitness consequences. Ann. Bot. 108, 1257-1268. doi: 10.1093/aob/mcr224

Ohba, H. (1978). Generic and infrageneric classification of the Old World Sedoideae (Crassulaceae). J. Fac. Sci. Univ. Tokyo 3, 138-139.

Ohba, H. (1988). "The alpine flora of the Nepal Himalayas: an introductory note," in The Himalayas Plants, eds H. Ohba and S. B. Malla (Tokyo: University of Tokyo Press), 19-46.

Omori, Y., Takayama, H., and Ohba, H. (2000). Selective light transmittance of translucent bracts in the Himalayan giant glasshouse plant Rheum nobile Hook.f. \& Thomson (Polygonaceae). Bot. J. Linn. Soc. 132, 19-27.

Otto, S. P. (2007). The evolutionary consequences of polyploidy. Cell 131, 452-462. doi: $10.1016 /$ j.cell.2007.10.022

Pan, J. T. (1995). A study on the tribe Astilbeae Miq. (Saxifragaceae). Acta Phytotaxon Sin. 33, 390-402.

Peterson, B. K., Weber, J. N., Kay, E. H., Fisher, H. S., and Hoekstra, H. E. (2012). Double digest RADseq: an inexpensive method for de novo SNP discovery and genotyping in model and non-model species. PLoS ONE 7:e37135. doi: 10.1371/journal.pone.0037135. doi: 10.1371/journal.pone.0037135

Qiao, C., Ran, J., Li, Y., and Wang, X. Q. (2007). Phylogeny and biogeography of Cedrus (Pinaceae) inferred from sequences of seven paternal chloroplast and maternal mitochondrial DNA regions. Ann. Bot. 100, 573-580. doi: 10.1093/aob/mcm 134

Qin, A. L., Wang, M. M., Cun, Y. Z., Yang, F. S., Wang, S. S., et al. (2013). Phylogeographic evidence for a link of species divergence of Ephedra in the Qinghai-Tibetan Plateau and adjacent regions to the Miocene Asian aridification. PLOS ONE 8:e56243. doi: 10.1371/journal.pone. 0056243

Qiu, Y. X., Fu, C. X., and Comes, H. P. (2011). Plant molecular phylogeography in China and adjacent regions: tracing the genetic imprints of Quaternary climate and environmental change in the world's most diverse temperate flora. Mol. Phylogenet. Evol. 59, 225-244. doi: 10.1016/j.ympev.2011. 01.012

Ran, J. H., Wei, X. X., and Wang, X. Q. (2006). Molecular phylogeny and biogeography of Picea (Pinaceae): implications for phylogeographical studies using cytoplasmic haplotypes. Mol. Phylogenet. Evol. 41, 405-419. doi: 10.1016/j.ympev.2006.05.039

Ree, R. H. (2005). Phylogeny and the evolution of floral diversity in Pedicularis (Orobanchaceae). Int. J. Plant Sci. 166, 595-613. doi: 10.1086/430191

Rowley, D. B., and Currie, B. S. (2006). Palaeo-altimetry of the late Eocene to Miocene Lunpola basin, central Tibet. Nature 439, 677-681. doi: 10.1038/nature04506

Royden, L. H., Burchfiel, B. C., and van der Hilst, R. D. (2008). The geological evolution of Tibetan Plateau. Science 321, 1054-1058. doi: 10.1126/science.1155371
Safer, S., Tremetsberger, K., Guo, Y. P., Kohl, G., Samuel, M. R., Stuessy, T. F., et al. (2011). Phylogenetic relationships in the genus Leontopodium (Asteraceae: Gnaphalieae) based on AFLP data. Bot. J. Linn. Soc. 165, 364-377. doi: 10.1111/j.1095-8339.2011.01117.x

Salvo, G., Ho, S. Y., Rosenbaum, G., Ree, R., and Conti, E. (2010). Tracing the temporal and spatial origins of island endemics in the Mediterranean region: a case study from the citrus family (Ruta L., Rutaceae). Syst. Biol. 59, 705-722. doi: 10.1093/sysbio/syq046

Schäfer, J. M., Tschudi, S., Zhao, Z. Z., Wu, X. H., Ivy-Ochs, S., et al. (2002). The limited influence of glaciation in Tibet on global climate over the past 170,000 yr Earth Planet Sci. Lett. 194, 287-297. doi: 10.1016/S0012-821X(01)00573-8

Shi, Y. F., Tang, M. C., and Ma, Y. Z. (1998). The relation of second rising in Qinghai-Tibetan Plateau and Asian monsoon. Sci. Chin. D 28, 263-271.

Shimono, A., Ueno, S., Gu, S., Zhao, X., Tsumura, Y., et al. (2010). Range shifts of Potentilla fruticosa on the Qinghai-Tibetan Plateau during glacial and interglacial periods revealed by chloroplast DNA sequence variation. Heredity 104, 534-542. doi: 10.1038/hdy.2009.158

Shrestha, K. K. (1997). Taxonomic revision of the Sino-Himalaya genus Cyananthus (Campanulaceae). Acta Phytotaxon. Sin. 35, 396-433.

Soltis, D. E., and Soltis, P. S. (1999). Polyploidy: recurrent formation and genome evolution. Trends Ecol. Evol. 14, 348-352. doi: 10.1016/S0169-5347(99)01638-9

Soltis, P. S., and Soltis, D. E. (2000). The role of genetic and genomic changes in the success of polyploids. Proc. Natl. Acad. Sci. U.S.A. 97, 7051-7057. doi 10.1073/pnas.97.13.7051

Song, B., Zhang, Z. Q., Stöcklin, J., Yang, Y., Niu, Y., Chen, J. G., et al. (2013). Multifunctional bracts enhance plant fitness during flowering and seed development in Rheum nobile (Polygonaceae), a giant herb endemic to the high Himalayas. Oecologia 172, 359-370. doi: 10.1007/s00442-012-2518-2

Song, B. H., Wang, X. Q., Wang, X. R., Ding, K. Y., and Hong, D. Y. (2003) Cytoplasmic composition in Pinus densata and population establishment of the diploid hybrid pine. Mol. Ecol. 12, 2995-3001. doi: 10.1046/j.1365-294X.2003. 01962.x

Song, B. H., Wang, X. Q., Wang, X. R., Sun, L. J., Hong, D. Y., and Peng, P. H. (2002) Maternal lineages of Pinus densata, a diploid hybrid. Mol. Ecol. 11, 1057-1063. doi: 10.1046/j.1365-294X.2002.01502.x

Spicer, R. A., Harris, N. B., Widdowson, W. M., Herman, A. B., Guo, S., Valdes, P. J., et al. (2003). Constant elevation of southern Tibet over the past 15 million years Nature 421, 622-624. doi: 10.1038/nature01356

Stebbins, G. L. (1940). The significance of polyploidy in plant evolution. Am. Nat. 74, 54-66. doi: 10.1086/280872

Stebbins, G. L. (1971). Chromosomal Evolution in Higher Plants. London: AddisonWesley.

Stebbins, G. L. (1984). Polyploidy and the distribution of the arctic-alpine flora: new evidence and a new approach. Bot. Helv. 94, 1-13.

Sun, H. (2002a). Tethys retreat and Himalayas-Hengduanshan Mountains uplift and their significance on the origin and development of the Sino-Himalayan elements and alpine flora. Acta Bot. Yunnan. 24, 273-288.

Sun, H. (2002b). Evolution of Arctic-Tertiary flora in Himalayan-Hengduan Mountains. Acta Bot. Yunnan. 24, 671-688.

Sun, H., and Li, Z. M. (2003). Qinghai-Tibet Plateau uplift and its impact on Tethys flora. Adv. Earth Sci. 18, 852-862.

Sun, H., Mclewin, W., and Fay, M. F. (2001). Molecular phylogeny of Helleborus (Ranunculaceae), with an emphasis on the eastern Asian-Mediterranean disjunction. Taxon 50, 1001-1018 doi: 10.2307/1224717

Sun, Y. S., Wang, A. L., Wan, D. S., Wang, Q., and Liu, J. Q. (2012). Rapid radiation of Rheum (Polygonaceae) and parallel evolution of morphological traits. Mol. Phylogenet. Evol. 63, 150-158. doi: 10.1016/j.ympev.2012.01.002

Terashima, I., Masuzawa, T., and Ohba, H. (1993). Photosynthetic characteristics of a giant alpine plant, Rheum nobile Hook.f. \& Thomson and of some other alpine species measured at $4300 \mathrm{~m}$, in the Eastern Himalayas Nepal. Oecologia 95, 194-201. doi: 10.1007/BF00323490

Thompson, J. D. (1999). Population differentiation in Mediterranean plants: insights into colonization history, and the evolution and conservation of endemic species. Heredity 82, 229-236. doi: 10.1038/sj.hdy.6885040

Tian, X., Luo, J., Wang, A., Mao, K., and Liu, J. Q. (2011). On the origin of the woody buckwheat Fagopyrum tibeticum (Parapteropyrum tibeticum) in the Qinghai-Tibetan Plateau. Mol. Phylogenet. Evol. 61, 515-520. doi: 10.1016/j.ympev.2011.07.001 
Tiffney, B. H. (1985). Perspectives on the origin of the floristic similarity between eastern Asia, and eastern North America. J. Arnold Arbor. 66, 73-94.

Tiffney, B. H., and Manchester, S. R. (2001). The use of geological and paleontological evidence in evaluating plant phylogeographic hypotheses in the Northern Hemisphere tertiary. Int. J. Plant Sci. 162, S3-S17. doi: 10.1086/323880

Tsukaya, H., Fujikawa, K., and Wu, S. G. (2002). Thermal insulation and accumulation of heat in the downy inflorescence of Saussurea medusa (Asteraceae) at high elevation in Yunnan, China. J. Plant Res. 115, 263-268. doi: 10.1007/s10265-002-0030-1

Tsukaya, H., and Tsuge, T. (2001). Morphological adaptation of inflorescences in plants that develop at low temperatures in early spring: the convergent evolution of "downy plants". Plant Biol. 3, 536-543. doi: 10.1055/s-2001-17727

Tu, T., Volis, S., Dillon, M. O., Sun, H., and Wen, J. (2010). Dispersals of Hyoscyameae and Mandragoreae (Solanaceae) from the New World to Eurasia in the early Miocene and their biogeographic diversification within Eurasia. Mol. Phylogenet. Evol. 57, 1226-1237. doi: 10.1016/j.ympev.2010.09.007

Turner, S., Arnaud, N., Liu, J., Rogers, N., Hawkesworth, C., Harris, N., et al. (1996). Post-collision, shoshonitic volcanism on the Tibetan plateau: implications for convective thinning of the lithosphere and the source of ocean island basalts. $J$. Petrol. 37, 45-71. doi: 10.1093/petrology/37.1.45

Wagner, C. E., Keller, I., Wittwer, S., Selz, O. M., Mwaiko, S., Greuter, L., et al. (2013), Genome-wide RAD sequence data provide unprecedented resolution of species boundaries and relationships in the Lake Victoria cichlid adaptive radiation. Mol. Ecol. 22, 787-798. doi: 10.1111/mec.12023

Wan, Y., Schwaninger, H. R., Baldo, A. M., Labate, J. A., Zhong, G. Y., and Simon, C. J. (2013). A phylogenetic analysis of the grape genus (Vitis L.) reveals broad reticulation and concurrent diversification during Neogene and Quaternary climate change. BMC Evol. Biol. 13:141 doi: 10.1186/1471-2148-13-141

Wang, A. L., Yang, M. H., and Liu, J. Q. (2005). Molecular phylogeny, recent radiation and evolution of gross morphology of the rhubarb genus Rheum (Polygonaceae) inferred from chloroplast DNA trnL-F sequences. Ann. Bot. 96, 489-498. doi: 10.1093/aob/mci201

Wang, B., and LinHo. (2002). Rainy season of the Asian-Pacific summer monsoon. J. Clim. 15, 386-398. doi: 10.1175/1520-0442(2002)015<0386:RSOTAP >2.0.CO;2

Wang, B. S., Mao, J. F., Gao, J., Zhao, W., and Wang, X. R. (2011a). Colonization of the Tibetan Plateau by the homoploid hybrid pine Pinus densata. Mol. Ecol. 20, 3796-3811. doi: 10.1111/j.1365-294X.2011.05157.x

Wang, L., Wu, Z.-Q., Bystriakova, N., Ansell, S. W., Xiang, Q.-P., et al. (2011b) Phylogeography of the Sino-Himalayan fern Lepisorus clathratus on "The Roof of the World". PLoS ONE 6:e25896. doi: 10.1371/journal.pone.0025896

Wang, H., and Li, D. Z. (2005). Pollination biology of four Pedicularis species (Scrophulariaceae) in northwestern Yunnan, China. Ann. Mo Bot. Gard. 92 127-138.

Wang, L. Y., Abbott, R. J., Zheng, W., Chen, P., Wang, Y. J., et al. (2009a). History and evolution of alpine plants endemic to the Qinghai-Tibetan Plateau: Aconitum gymnandrum (Ranunculaceae). Mol. Ecol. 18, 709-721. doi: 10.1111/j.1365294X.2008.04055.X

Wang, Y., Liu, Y. F., Liu, S. B., and Huang, H. W. (2009b). Molecular phylogeny of Myricaria (Tamaricaceae): implications for taxonomy and conservation in China. Bot. Stud. 50, 343-352.

Wang, Y. J., Susanna, A., von Raab-Straube, E., Milne, R., and Liu, J. Q. (2009c). Island-like radiation of Saussurea (Asteraceae: Cardueae) trigged by uplifts of the Qinghai-Tibetan Plateau. Biol. J. Linn. Soc. 97, 893-903. doi: 10.1111/j.10958312.2009.01225.x

Wang, Z., Gerstein, M., and Snyder, M. (2009d). RNA-Seq: a revolutionary tool for transcriptomics. Nat. Rev. Genet. 10, 57-63. doi: 10.1038/nrg2484

Wang, W., Chen, Z.-D., Liu, Y., Li, R.-Q., and Li, J.-H. (2007a). Phylogenetic and biogeographic diversification of Berberidaceae in the Northern Hemisphere. Syst. Bot. 32, 731-742. doi: 10.1600/036364407783390791

Wang, Y. J., Liu, J. Q., and Miehe, G. (2007b). Phylogenetic origins of the Himalayan endemic Dolomiaea, Diplazoptilon and Xanthopappus (Asteraceae: Cardueae) based on three DNA regions. Ann. Bot. 99, 311-322. doi: 10.1093/aob/mcl259

Wang, X. R., Szmidt, A. E., and Savolainen, O. (2001). Genetic composition and diploid hybrid speciation of a high mountain pine, Pinus densata, native to the Tibetan plateau. Genetics 159, 337-346.

Wang, Y., Liu, Y. F., Liu, S. B., and Huang, H. W. (2006). Geographic distribution and current status and conservation strategy of the genus Myricaria in China. J. Wuhan Bot. Res. 24, 455-463.
Wang, Y.-J., Li, X.-J., Hao, G., and Liu, J.-Q. (2004). Molecular phylogeny and biogeography of Androsace (Primulaceae) and the convergent evolution of cushion morphology. Acta Phytotaxon. Sin. 42, 481-499.

Wen, J. (1998). Evolution of the eastern Asian and eastern North American disjunct pattern: insights from phylogenetic studies. Korean J. Plant Taxon. 28, 63-81.

Wen, J. (1999). Evolution of eastern Asian and eastern North American disjunct distributions in flowering plants. Annu. Rev. Ecol. Syst. 30, 421-455. doi 10.1146/annurev.ecolsys.30.1.421

Wen, J. (2001). Evolution of eastern Asian and eastern North American biogeographic pattern: a few additional issues. Int. J. Plant Sci. 162, S117-S122. doi: $10.1086 / 322940$

Wen, J. (2011). Systematics and biogeography of Aralia L. (Araliaceae): revision of Aralia sects. Aralia, Humiles, Nanae, and Sciadodendron. Contrib. U.S. Natl. Herb. $57,1-172$.

Wen, J., Ickert-Bond, S., Nie, Z.-L., and Li, R. (2010). “Timing and modes of evolution of eastern Asian-North American biogeographic disjunctions in seed plants," in Darwin's Heritage Today: Proceedings of the Darwin 200 Beijing International Conference, eds M. Long, H. Gu, and Z. Zhou (Beijing: Higher Education Press), 252-269.

Wen, J., and Ickert-Bond, S. M. (2009). Evolution of the Madrean-Tethyan disjunctions and the North and South American amphitropical disjunctions in plants. $J$. Syst. Evol. 47, 331-348. doi: 10.1111/j.1759-6831.2009.00054.x

Wen, J., Jansen, R. K., and Zimmer, E. A. (1996). "Phylogenetic relationships and DNA sequence divergence of eastern Asian and eastern North American disjunct plants," in Current Topics on Molecular Evolution, eds M. Nei and N. Takahata (University Park, PA: Pennsylvania State University/Hayama: The Graduate University for Advanced Studies), 37-44.

Wen, J., Ree, R. H., Ickert-Bond, S. M., Nie, Z.-L., and Funk, V. (2013). Biogeography: where do we go from here? Taxon 62, 912-927.

Wen, J., Shi, S., Jansen, R. K., and Zimmer, E. A. (1998). Phylogeny and biogeography of Aralia sect. Aralia (Araliaceae). Am. J. Bot. 85, 866-875. doi: 10.2307/2446422

Wen, J., and Zimmer, E. A. (1996). Phylogeny of Panax L. (the ginseng genus, Araliaceae): inference from ITS sequences of nuclear ribosomal DNA. Mol. Phylogenet. Evol. 5, 167-177. doi: 10.1006/mpev.1996.0069

Wright, J. W. (1955). Species crossability in spruce in relation to distribution and taxonomy. For. Sci. 1, 319-349.

Wu, L.-L., Cui, X.-K., Milne, R. I., Sun, Y.-S., and Liu, J. Q. (2010). Multiple autopolyploidizations and range expansion of Allium przewalskianum Regel (Alliaceae) in the Qinghai-Tibetan Plateau. Mol. Ecol. 19, 1691-1704. doi: 10.1111/j.1365-294X.2010.04613.x

Wu, S. G, Yang Y. P., and Fei, Y. (1995). On the flora of the alpine region in the Qinghai-Xizang (Tibet) plateau. Acta Bot. Yunnan. 17, 233-250.

Wu, Z. Y. (1988). Hengduan Mountain flora and her significance. J. Jpn. Bot. 63 , 297-311.

Xiang, Q. Y., Zhang, H., Ricklefs, R. E., Qian, H., Chen, Z. D., Wen, J., et al. (2004). Regional differences in rates of plant speciation and molecular evolution: a comparison between eastern Asia and eastern North America. Evolution 58, 2175-2184.

Xie, L., Wagner, W. L., Ree, R. H., Berry, P. E., and Wen, J. (2009). Molecular phylogeny, divergence time estimates, and historical biogeography of Circaea (Onagraceae) in the Northern Hemisphere. Mol. Phylogenet. Evol. 53, 995-1009. doi: 10.1016/j.ympev.2009.09.009

Xie, L., Wen, J., and Li, L.-Q. (2011). Phylogenetic analyses of Clematis (Ranunculaceae) based on sequences of nuclear ribosomal ITS and three plastid regions. Syst. Bot. 36, 907-921. doi: 10.1600/036364411X604921

Xie, L., Yang, Z.-Y., Wen, J., Li, D.-Z., and Yi, T.-S. (2014). Biogeographic history of Pistacia (Anacardiaceae), emphasizing the evolution of the Madrean-Tethyan and the eastern Asian-Tethyan disjunctions. Mol. Phylogenet. Evol. (in press).

Xie, X. Y., Gu, Z. J., and Wu, Q. A. (1992). Cytological studies of the genus Nomocharis and its related genera. Acta Phytotaxon. Sin. 30, 487-497.

Xu, T. T., Abbott, R. J., Milne, R. I., Mao, K. S., Du, F. K., Wu, G. L., et al. (2010). Phylogeography and allopatric divergence of cypress species (Cupressus L.) in the Qinghai-Tibetan Plateau and adjacent regions. BMC Evol. Biol. 10:194. doi: 10.1186/1471-2148-10-194

Yang, F.-S., Li, Y. F., Ding, X., and Wang, X. Q. (2008a). Extensive population expansion of Pedicularis longiflora (Orobanchaceae) on the Qinghai-Tibetan Plateau and its correlation with Quaternary climate change. Mol. Ecol. 17, 5135-5145. doi: 10.1111/j.1365-294X.2008.03976.x 
Yang, Y., Körner, Ch., and Sun, H. (2008b). The ecological significance of pubescence in Saussurea medusa, a high-elevation Himalayan" Woolly Plant". Arct. Antarct. Alp. Res. 40, 250-255. doi: 10.1657/1523-0430(07-009)[YANG]2.0.CO;2

Yang, F.-S., Qin, A.-L., Li, Y.-F., and Wang, X. Q. (2012). Great genetic differentiation among populations of Meconopsis integrifolia and its implication for plant speciation in the Qinghai-Tibetan Plateau. PLoS ONE 7:e37196. doi: 10.1371/journal.pone.0037196

Yang, F. S., Wang, X. Q., and Hong, D. Y. (2003). Unexpected high divergence in nrDNA ITS and extensive parallelism in floral morphology of Pedicularis (Orobanchaceae). Plant Syst. Evol. 240, 91-105. doi: 10.1007/s00606-003-0005-2

Yang, H. B., Holmgren, N. H., and Mill, R. R. (1998). “Pedicularis L.," in Flora of China, Vol. 18, eds Z. Y. Wu and P. H. Raven (Beijing: Science Press/St Louis, MO Missouri Botanical Garden Press), 97-209.

Yang, S. J., Dong, H. L., and Lei, F. M. (2009). Phylogeography of regional fauna on the Tibetan Plateau: a review. Prog. Natl. Acad. Sci. U.S.A. 19, 789-799. doi: 10.1016/j.pnsc.2008.10.006

Yang, Y., and Sun, H. (2009). The bracts of Saussurea velutina (Asteraceae) protect inflorescences from fluctuating weather at high elevations of the Hengduan mountains, southwestern China. Arct. Antarct. Alp. Res. 41, 515-521. doi: 10.1657/1938-4246-41.4.515

Yi, T.-S., Miller, A. J., and Wen, J. (2004). Phylogenetic and biogeographic diversification of Rhus (Anacardiaceae) in the Northern Hemisphere. Mol. Phylogenet. Evol. 33, 861-879. doi: 10.1016/j.ympev.2004.07.006

Yi, T.-S., Wen, J., Golan-Goldhirsh, A., and Parfitt, D. E. (2008). Phylogenetics and reticulate evolution in Pistacia (Anacardiaceae). Am. J. Bot. 95, 241-251. doi: 10.3732/ajb.95.2.241

Yokoyama, J., Suzuki, M., Iwatsuki, K., and Hasebe, M. (2000). Molecular phylogeny of Coriaria, with special emphasis on the disjunct distribution. Mol. Phylogenet. Evol. 14, 11-19. doi: 10.1006/mpev.1999.0672

Yoshida, T. (2002). "Adaptive strategies of alpine plants in Nepal," in Himalayan Botany in the Twentieth and Twenty-first Centuries, eds S. Noshiro and K. R. Rajbhanselari (Tokyo: The Society of Himalayan Botany), 105-111.

Yuan, Q., and Yang, Q. E. (2006). Polyploidy in Aconitum subgenus Lycoctonum (Ranunculaceae). Bot. J. Linn. Soc. 150, 343-353. doi: 10.1111/j.10958339.2006.00468.x

Yuan, Q., and Yang, Q. E. (2008). Low incidence of polyploids and high uniformity of karyotypes displayed by Delphinium (Ranunculaceae) in the Hengduan Mountains region of south-west China. Bot. J. Linn. Soc. 158, 172-188. doi: 10.1111/j.1095-8339.2008.00849.x

Yue, J. P., Gu, Z. J., Al-Shehbaz, I. A., and Sun, H. (2004). Cytological studies on the Sino-Himalayan endemic Solms-laubachia (Brassicaceae) and two related genera. Bot. J. Linn. Soc. 145, 77-86. doi: 10.1111/j.1095-8339.2003.00268.x

Yue, J. P., Sun, H., David, B. A., Li, J. H., Al-Shehbaz, I. A., and Ree, R. (2009) Molecular phylogeny of Solms-laubachia (Brassicaceae) s.l., based on multiple nuclear and plastid DNA sequences, and its biogeographic implications. J. Syst. Evol. 47, 402-415. doi: 10.1111/j.1759-6831.2009.00041.x

Zha, H.-G., Milne, R. I., and Sun, H. (2008). Morphological and molecular evidence of natural hybridization between two distantly related Rhododendron species from the Sino-Himalaya. Bot. J. Linn. Soc. 156, 119-129. doi: 10.1111/j.1095-8339.2007.00752.x

Zha, H.-G., Milne, R. I., and Sun, H. (2010). Asymmetric hybridization in Rhododendron agastum: a hybrid taxon comprising mainly F1s in Yunnan, China. Ann. Bot. 105, 89-100 doi: 10.1093/aob/mcp267

Zhang, D., Liu, B., Zhao, C., Lu, X., Wan, D., Ma, F., et al. (2010). Ecological functions and differentially expressed transcripts of translucent bracts in an alpine 'glasshouse' plant Rheum nobile (Polygonaceae). Planta 231, 1505-1511. doi: 10.1007/s00425-010-1133-x

Zhang, M. L., and Fritsch, P. W. (2010). Evolutionary response of Caragana (Fabaceae) to Qinghai-Tibetan Plateau uplift and Asian interior aridification. Plant Syst. Evol. 288, 191-199. doi: 10.1007/s00606-010-0324-Z

Zhang, Y. H., Volis, S., and Sun, H. (2010c). Chloroplast phylogeny and phylogeography of Stellera chamaejasme on the Qinghai-Tibet Plateau and in adjacent regions. Mol. Phylogenet. Evol. 57, 1162-1172. doi: 10.1016/j.ympev.2010.08.033

Zhang, J.-Q., Meng, S.-Y., Wen, J., and Rao, G.-Y. (2014). Phylogenetic relationships of Rhodiola (Crassulaceae) based on ITS, trnL-F, and psbA-trnH sequences. Syst. Bot. (in press).
Zhang, J.-W., Nie, Z.-L., and Sun, H. (2009a). Cytological study on the genus Syncalathium (Asteraceae-Lactuceae), an endemic taxon to alpine scree of the Sino-Himalayas. J. Syst. Evol. 47, 226-230. doi: 10.1111/j.1759-6831.2009.00024.x

Zhang, X. L., Wang, Y. J., Ge, X. J., Yuan, Y. M., Yang, H. L., and Liu, J. Q. (2009b). Molecular phylogeny and biogeography of Gentiana sect. Cruciata (Gentianaceae) based on four chloroplast DNA datasets. Taxon 58, 862-870.

Zhang, J. W., Nie, Z.-L., Wen, J., and Sun, H. (2011a). Molecular phylogeny and biogeography of three closely related genera, Soroseris, Stebbinsia, and Syncalathium (Asteraceae, Cichorieae), endemic to the Tibetan Plateau, SW China. Taxon 60, $15-26$.

Zhang, J.-W., Boufford, D.-E., and Sun, H. (2011b). Parasyncalathium J.W.Zhang, Boufford \& H. Sun (Asteraceae, Cichorieae): a new genus endemic to the Himalaya-Hengduan Mountains. Taxon 60, 1678-1684.

Zhang, J.-W., Sun, H., and Nie, Z.-L. (2007). Karyological studies on the Sino-Himalayan endemic Soroseris and two related genera of tribe Lactuceae (Asteraceae). Bot. J. Linn. Soc. 154, 79-87. doi: 10.1111/j.1095-8339.2007.00644.x

Zhang, M. L., Kang, Y., Zhong, Y., and Sanderson, S. C. (2012a). Intense uplift of the Qinghai-Tibetan Plateau triggered rapid diversification of Phyllolobium (Leguminosae) in the Late Cenozoic. Plant Ecol. Div. 5, 491-499. doi: 10.1080/17550874.2012.727875

Zhang, Z. S., Flatoy, F., Wang, H. J., Bethke, I., Bentsen, M., and Guo, Z. T. (2012b). Early Eocene Asian climate dominated by desert and steppe with limited monsoons. J. Asian Earth Sci. 44, 24-35. doi: 10.1016/j.jseaes.2011.05.013

Zhang, Y. L., Li, B. Y., and Zheng, D. (2002). A discussion on the boundary and area of the Tibetan Plateau in China. Geogr. Res. 21, 1-8.

Zhou, W., Yan, F., Fu, J., Wu, S., Murphy, R. W., Che, J., et al. (2013a). River islands, refugia and genetic structuring in the endemic brown frog Rana kukunoris (Anura, Ranidae) of the Qinghai-Tibetan Plateau. Mol. Ecol. 22, 130-142. doi: $10.1111 / \mathrm{mec} .12087$

Zhou, Z., Hong, D., Niu, Y., Li, G., Nie, Z.-L., Wen, J., et al. (2013b). Phylogenetic and biogeographic analyses of the Sino-Himalayan endemic genus Cyananthus (Campanulaceae) and implications for the evolution of its sexual system. Mol. Phylogenet. Evol. 68, 482-497. doi: 10.1016/j.ympev.2013. 04.027

Zhu, W.-D., Nie, Z.-L., Wen, J., and Sun, H. (2013). Molecular phylogeny and biogeography of Astilbe (Saxifragaceae) in Asia and eastern North America. Bot. J. Linn. Soc. 171, 377-394. doi: 10.1111/j.1095-8339.2012.01318.x

Zhu, X.-F., Li, Y., Wu, G.-L., Fang, Z.-D., Li, Q.-J., and Liu, J.-Q. (2009). Molecular and morphological evidence for natural hybridization between Primula secundilfora Franchet and P. possonii Franchet (Primulaceae). Acta Biol. Crac. Bot. 51/2, $29-36$.

Zou, J.-B., Peng, X.-L., Li, L., Liu, J. Q., Miehe, G., and Opgenoorth, L. (2012). Molecular phylogeography and evolutionary history of Picea likiangensis in the Qinghai-Tibetan Plateau inferred from mitochondrial and chloroplast DNA sequence variation. J. Syst. Evol. 50, 341-350. doi: 10.1111/j.1759-6831.2012. 00207.x

Zuo, Y., Chen, Z., Kondo, K., Funamoto, T., Wen, J., and Zhou, S. (2011). DNA barcoding of Panax species. Planta Med. 72, 182-187. doi: 10.1055/s-0030-1250166

Conflict of Interest Statement: The authors declare that the research was conducted in the absence of any commercial or financial relationships that could be construed as a potential conflict of interest.

Received: 30 October 2013; accepted: 06 January 2014; published online: 12 February 2014.

Citation: Wen J, Zhang J-Q, Nie Z-L, Zhong Y and Sun H (2014) Evolutionary diversifications of plants on the Qinghai-Tibetan Plateau. Front. Genet. 5:4. doi: 10.3389/fgene.2014.00004

This article was submitted to Evolutionary and Population Genetics, a section of the journal Frontiers in Genetics.

Copyright (C) 2014 Wen, Zhang, Nie, Zhong and Sun. This is an open-access article distributed under the terms of the Creative Commons Attribution License (CC BY). The use, distribution or reproduction in other forums is permitted, provided the original author(s) or licensor are credited and that the original publication in this journal is cited, in accordance with accepted academic practice. No use, distribution or reproduction is permitted which does not comply with these terms. 